\title{
Ecological and economic impacts of wildfires on an Appalachian oak forest in southern West Virginia
}

\author{
Katharina U. Mueller Wood \\ West Virginia University
}

Follow this and additional works at: https://researchrepository.wvu.edu/etd

\section{Recommended Citation}

Wood, Katharina U. Mueller, "Ecological and economic impacts of wildfires on an Appalachian oak forest in southern West Virginia" (2010). Graduate Theses, Dissertations, and Problem Reports. 4673. https://researchrepository.wvu.edu/etd/4673

This Thesis is protected by copyright and/or related rights. It has been brought to you by the The Research Repository @ WVU with permission from the rights-holder(s). You are free to use this Thesis in any way that is permitted by the copyright and related rights legislation that applies to your use. For other uses you must obtain permission from the rights-holder(s) directly, unless additional rights are indicated by a Creative Commons license in the record and/ or on the work itself. This Thesis has been accepted for inclusion in WVU Graduate Theses, Dissertations, and Problem Reports collection by an authorized administrator of The Research Repository @ WVU. For more information, please contact researchrepository@mail.wvu.edu. 


\title{
Ecological and Economic Impacts of Wildfires
} on an Appalachian Oak Forest in Southern West Virginia

\author{
Katharina U. Mueller Wood
}

Thesis submitted to the Davis College of Agriculture, Natural Resources and Design at West Virginia University in partial fulfillment of the requirements

for the degree of

\section{Master of Science}

in

Forestry

\section{Eric Heitzman, Ph.D., Chair}

James Rentch, Ph.D.

John Brooks, Ph.D.

Michael Strager, Ph.D.

Division of Forestry and Natural Resources

Morgantown, West Virginia

2010 


\title{
ABSTRACT \\ Ecological and Economic Impacts of Wildfires on an Appalachian Oak Forest in Southern West Virginia
}

\author{
Katharina U. Mueller Wood
}

Oaks (Quercus spp.) are considered a fire adapted species and fire disturbances throughout the lifecycle have been proposed to be necessary for maintaining oak dominated stands. Wildfire has been blamed for significant losses in sawtimber volume. A total of 164 points were sampled in stands that had experienced between zero to six wildfires over 36 years in Cabwaylingo State Forest (CSF), West Virginia. The wildfires have affected different strata and species of forest vegetation in different ways. While total overstory density decreased from 242 to 38 TPA with increasing fire frequency, oak density was highest in areas of three fires. Although overall basal area decreased from 171 to $52 \mathrm{ft}^{2} / \mathrm{ac}$, oak basal area remained fairly constant at around $60 \mathrm{ft}^{2} / \mathrm{ac}$. Oaks in smaller $(<8$ inches) DBH classes were most abundant in areas of two to four wildfires. Total density of sapling sized stems increased with heightened fire occurrence. Oak saplings were significantly highest in density in areas of four fires. Neither oak nor non-oak seedling densities showed significantly differences by fire occurrences. Aggregate oak seedling height, however, was highest in areas that had burned four times. A regeneration assessment method by Steiner et al. (2008) revealed that expected oak stocking 30 years after complete harvest would be $73 \%$ in areas of three burns, decreasing with lower or higher fire occurrences. Our results indicate that oak advance reproduction is most competitive over non-oak species in those areas of CSF that have experienced two to four wildfires. Sawtimber volume loss due to cull increased from 181 to $752 \mathrm{Bdft} / \mathrm{ac}$ in areas experiencing from zero to six fire occurrences. Total net volume and net dollar value declined with increasing fire frequency ranging from 10,924 to $4,906 \mathrm{Bdft} / \mathrm{ac}$ and $\$ 1,208$ to 589/ac, respectively; this is equal to a value decline of nearly 54\%. 


\section{ACKNOWLEDGEMENTS}

I would like to thank my graduate committee advisor, Dr. Eric Heitzman, for his advice, guidance, and help throughout this research project. He has given me the opportunity to work on a project that was very interesting and enjoyable to me. For his patience, encouragement, and support I am very grateful. The freedom he provided to align the process with my professional interests and personal life is invaluable and will not be forgotten. I furthermore appreciate all the time and advice that my other committee members, Dr. James Rentch, Dr. John Brooks, and Dr. Michael Strager, contributed to problem solving and the improvement of my study. Without their help, this project would not have been possible. Thanks is also due to the WVU Division of Forestry and Natural Resources and all its integral faculty and staff for their contributions to my educational development and the opportunities they have provided for me to work with and learn from some wonderful people.

I would also like to thank the West Virginia Division of Forestry for their interest in and funding of the study. I extend my gratitude to everyone at the Region 3 Milton Office for being so helpful and forthcoming during the process of assembling fire records and making me feel welcome; a special thanks to Kevin Arnold and Kyra Johnson. The forestry staff at Cabwaylingo State Forest provided me with priceless advice, insight, and moral support. Thank you for all of the insider tips and the extra time you took out of your days to help me familiarize myself with the research location; my special gratitude to Lynette Simko and Edward Messer. Thank you, to my field assistant Candace Butler, for all your hard work and positive attitude even on rainy, buggy, and hot field days in strenuous terrain. Your ability to spot rattlesnakes came in handy.

Last but not least, a big thanks to my family, especially to my husband Bryan. Your humor in times of frustration and support in stressful times have helped me stay focused. The 
moral support and encouragement you've provided have helped me keep everything in perspective and have enabled me to finish my work. 


\section{TABLE OF CONTENTS}

Page

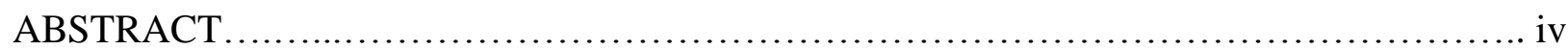

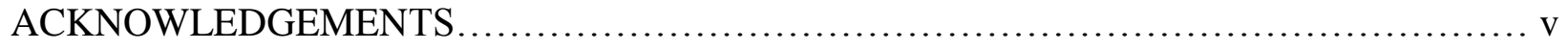

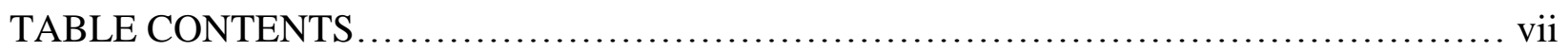

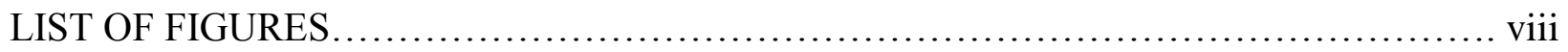

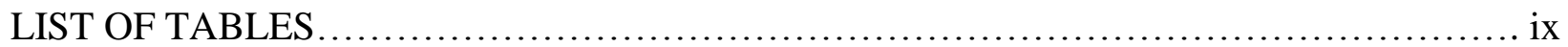

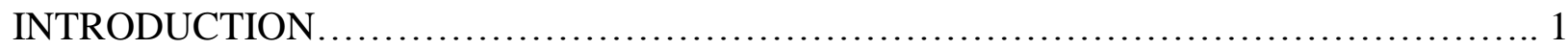

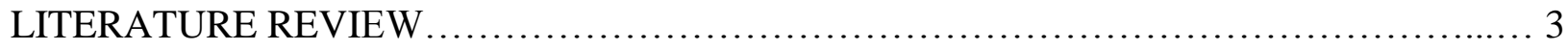

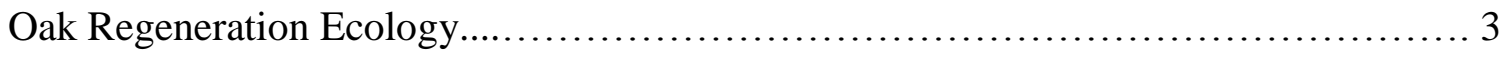

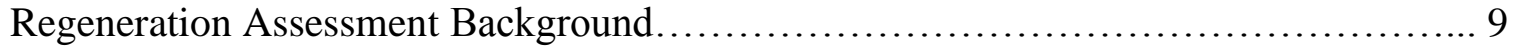

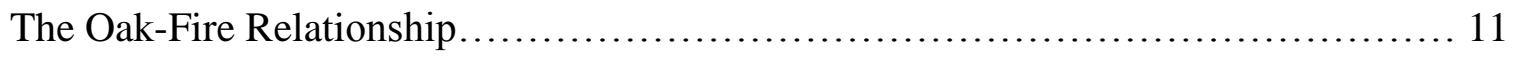

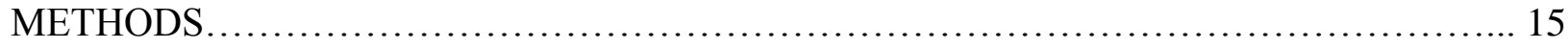

Study Area............................................................... 15

Fire Map Creation...................................................... 17

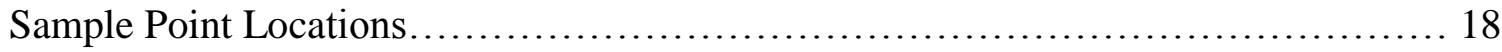

Data Collection............................................................. 22

Data Analysis................................................................ 23

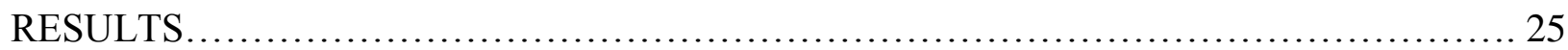

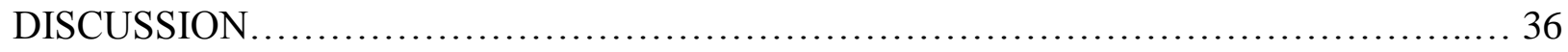

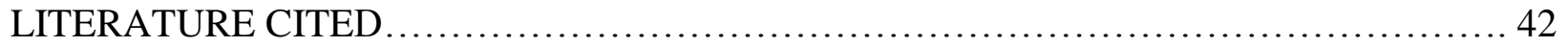




\section{LIST OF FIGURES}

Figure $\quad$ Page

1 Location of Cabwaylingo State Forest in West Virginia. ............................. 16

2 Fire occurrences in Cabwaylingo State Forest 1972-2007............................. 19

3 Sample point locations in Cabwaylingo State Forest. ................................. 20

4 Size class distribution of overstory trees in Cabwaylingo State Forest. .................... 29 


\section{LIST OF TABLES}

Table

Page

1 Physical summary of sample point locations at Cabwaylingo State Forest.

2 Mean overstory density per acre (TPA) of living trees $\geq 2$ inches DBH in Cabwaylingo State Forest.

3 Mean overstory basal area per acre $\left(\mathrm{ft}^{2} / \mathrm{ac}\right)$ of living trees $\geq 2$ inches DBH in Cabwaylingo State Forest.

4 Mean sapling density per acre of living stems $\geq 5 \mathrm{ft}$ tall and $<2$ inches DBH in Cabwaylingo State Forest.

5 Mean seedling density per acre of living stems $<5 \mathrm{ft}$ tall in Cabwaylingo State Forest.

6 Summary of oak regeneration characteristics in Cabwaylingo State Forest.

7 Wildfire impact on timber volume and value in Cabwaylingo State Forest. 34 


\section{INTRODUCTION}

The role of fire as a creative as well as a destructive force has been debated by civilizations since mythological times. Although modern sciences are working hard to divest fire of its mythical reputation, much of the controversy has remained. Fire is used widely to prepare plots for new generations of plants of all kinds, yet is dreaded once a favorable crop has become established. We believe species and whole forest systems have adapted to weather recurring fire regimes, yet we try to 'save' our forest from fires. Smokey the Bear has become the face of wildfire control and contributed to a fire-suppression mentality in the United States.

Pondering what came first, the oak or the acorn, may be a moot point in the southern Appalachians where oaks (Quercus spp.) developing from acorns face seemingly unconquerable odds of reaching maturity and oaks sprouting from preexisting stumps are a large part of the population. The complexity of oak regeneration is magnified by its variability across microclimates, seasonal and individual variation of acorn production, ever-changing disturbance patterns of forests, and the interaction between all of the above (Hodges and Gardiner 1992). The physiology of individuals and dynamics within populations must be understood so that management adjustments may be made.

While fire has been suggested to facilitate oak regeneration, it is without a doubt a timber consumer that does not heed market prices. A valuable timber crop that takes decades to mature can be essentially made worthless over night by an uncontrolled wildfire. In the Appalachians, where economic competitiveness and livelihoods of many people have depended on forest productivity since the first settlements, forest managers face the daunting task of weighing the benefits and detriments of fire in their woods. This is especially true for one of West Virginia's fiercest wildfire regions and one of the forests therein: Cabwaylingo State Forest (CSF). 
The West Virginia Division of Forestry (2001) states on their website: "Cabwaylingo State Forest has experienced many destructive forest fires, due in large part to arson, debris burning, and moon-shining. Because of the severity of many of the forest fires, parts of the Forest were set back hundreds of years in developing to maturity." While some have argued that fire is imperative to achieve adequate oak advanced reproduction (Barnes and Van Lear 1998, Brose et al. 2001), others point out its negative impacts on timber quality and value (Lowell et al. 1992). With present concerns about oak reproduction in Appalachian hardwood forests in the light of fire suppression and the call for management plans incorporating controlled burning, Cabwaylingo offered itself as an opportune case study of the impact of repeated wildfire occurrences on oak regeneration as well as sawtimber value loss.

In this paper we spatially depict the wildfires that have occurred in CSF since 1972 . We then describe stands that have been subject to repeated burning in terms of conventional forestry parameters like species composition, density, and basal area. Furthermore, we aim to evaluate the effect of different wildfire regimes on the advanced reproduction with a special focus on oaks. Lastly, we briefly review the impact wildfires in CSF have on the monetary value of forest stands. 


\section{LITERATURE REVIEW}

\section{Oak Regeneration Ecology}

The early regeneration of oaks is conventionally referred to as seedlings. The survival of oaks on a population scale, however, is impacted by two more juvenile growth forms, namely seedling sprouts and stump sprouts. Seedling sprouts result from the dieback and resprouting of seedlings one or multiple times. Stump sprouts arise from the otherwise dormant buds of killed, injured, or felled trees. All three kinds of growth forms are commonly termed reproduction by silviculturists and advanced reproduction in a pre-cut assessment of a stand (Johnson 1992).

Seed-producing age in most eastern oak species is reached between 15-25 years of age exceptions including sprout-origin chestnut oaks (Quercus prinus L.), which may reach maturity as soon as age 3 (Johnson and Shifley 2002). From pollination to acorn maturity, red oaks require two growing seasons, while white oaks complete the cycle in just one (Beck 1992, Johnson and Shifley 2002). Although annual flower production is abundant and consistent, acorn crops can vary greatly in yield from year to year. Variations are mainly due to differences in crown position, with higher light exposure being linked to greater productivity (Sharp and Sprague 1967). Acorn yields generally increase with crown size as reflected by diameter and therefore presumably age. Yields increase to a certain age, level off, and then decrease (Beck 1992, Johnson 1992). Premature abscission of developing acorns averages $70 \%$ (Feret et al. 1982) and can reach up to $99 \%$ of the crop at times (Williamson 1966).

Weather conditions at time of acorn development, insect infestation, as well as poorly understood yet widely observed differences among individual trees are all believed to contribute to the well known phenomenon of bumper crops (Johnson 1992, Johnson and Shifley 2002). These inherent factors in individuals oftentimes make the influence of environmental factors on 
abscission and yield insignificant. A good mast year is often followed by 2-4 years of poor acorn production in white oaks, while cycles in red oak are less distinctive. There is, however, no empirical evidence that synchronization occurs among the same species within a stand. Alternatively, it has been suggested that some individual trees are inherently periodic in producing acorns while others are not; cycles of periodic producers may coincidently come together and then begin to deviate again, creating the observation of bumper crop years on a population level (Johnson and Shifley 2002).

Even in years of good crop production, acorn predation by insects, birds, fungi, and mammals affects immature as well as mature acorns, causing many never to reach the ground at all. Destruction by insects, such as acorn weevils, moths, acorn gall wasps, and nitidulid sap beetles can account for the loss of 50-100\% of a given crop (Johnson and Shifley 2002). Escape from predation and successful germination of acorns that do reach the ground is more than doubled if the seed is buried by natural mechanisms such as seed caching by rodents and some birds (Hodges and Gardiner 1992, Johnson and Shifley 2002). Patches of high and low oak regeneration density are found beneath stands of essentially equal acorn production. Site factors other than acorn yield are important influences on the successful establishment of seedlings (Carvell and Tryon 1961).

White oaks initiate germination in the fall of the same year they mature while red oaks do not germinate until the following spring (Johnson and Shifley 2002). While being covered by soil and leaf litter greatly increases the survival of acorns, their developmental fate depends largely on the location at which they were deposited (Hodges and Gardiner 1992, Johnson 1992). While the odds of an individual acorn to fully develop, safely reach the ground, and germinate 
are very low, germination seldom acts as the limiting factor for seedling establishment (Lorimer 1992).

During germination, oak seedlings quickly develop a strong tap root that functions primarily for food storage. The tap root is covered by thick corky tissue prohibiting it from water and nutrient absorption. The first flush of vegetative growth typically results in seedling growth up to 6 inches. Following this immediate growth spurt, the shoot enters a lag phase during which a new terminal bud is formed. Under good site and weather conditions oak seedlings may flush multiple times during a growing season, while under low light conditions, first-year seedlings usually only flush once (Hodges and Gardiner 1992). The terminal buds act as a preparatory storage unit in anticipation of next year's growth (Johnson and Shifley 2002). This conservative growing approach is in contrast with seedlings of other species that may utilize available resources continuously or are less limited by light conditions. The oaks' growth strategy furthermore prevents the seedling from growing quickly even if released during this stage (Hodges and Gardiner 1992). While shoot growth in oaks is a repetitive series of flushes and lags, root growth is essentially continuous. Up to $95 \%$ of photosynthates generated by the leaves in between flushes are translocated into the lower stem and roots. Because seedlings spend much of their time in lagging stages, this pattern of carbon allocations results in an increasingly large root:shoot ratio (Johnson and Shifley 2002).

While comparatively high in water efficiency, oak seedlings are relatively intolerant of shade (Johnson and Shifley 2002), especial low shade as created by a dense understory (Johnson 1992). Oak forests that have become established are often successionally displaced by other species that have a more indeterminate shoot development strategy and/or are more tolerant of shade. Oak seedlings grow slowly, and although they may eventually reach significant height 
and possibly maturity under conditions of low competition and abundant light, most seedlings under natural conditions typically last only one to three years before they die back and perhaps resprout several times - at which time they would be considered seedling sprouts (Johnson 1992).

Seedling sprouts originate from otherwise dormant buds located anywhere between the root collar and the terminal bud. These buds are suppressed by growth regulators produced in the leaves. Activation of these buds, and thus resprouting, may be initiated through total or partial dieback of the shoot (Hodges and Gardiner 1992, Johnson 1992, Johnson and Shifley 2002). Evidence of this resprouting strategy is more commonly demonstrated on dry sites where seedling shoots are soon compromised having to endure high water stress along with low light intensities. Seedlings on such xeric sites exist near the compensation point at which the rate of photosynthesis is equal to the rate of respiration - a stressor that reinforces oak's strategy of translocating most of its photosynthates produced during the juvenile growth period to its root system. The periodic dieback of the shoot minimizes it as an energy sink; seedlings that survive this process eventually develop relatively large root systems further increasing the root:shoot ratio (Johnson and Shifley 2002). This accumulation of resources in the root stock allows for quick response to release, making the otherwise slow-growing oak more competitive. Additionally, the vascular system of seedling sprouts may develop differently than that of undisturbed seedlings and allow for faster water movement throughout the plant due to larger vessel size (Hodges and Gardiner 1992). Hence, seedling sprouts are not only faster in responding to favorable environmental cues but are also more resistant to water stress due to higher conductive efficiency.

In general, seedling sprouts are more resistant to environmental stressors; larger stems with more developed root systems show lower mortality than smaller seedlings and seedling 
sprouts (Sander 1972). For example, northern red oak (Quercus rubra L.) maintains a stresstolerant growth strategy when compared to yellow-poplar (Liriodendron tulipifera L.). Red oak is better adapted to grow in moderately low levels of moisture and nutrients. Yellow-poplar, on the other hand, captures resources more rapidly than oak in productive environments and can easily outcompete oaks (Kolb and Steiner 1990). Physiological characteristics of oaks that are favorable to survival in dry-mesic or xeric conditions include: (1) high rates of photosynthesis and only small decreases with increasing soil and atmospheric drought, (2) high water use efficiency, (3) slow stomatal closure and high leaf conductance during drought, (4) low water potential for stomatal closure, and (5) greater osmotic and elastic adjustments in the leaves (Abrams 1990). In the Missouri Ozarks, oak advance reproduction over 4.5 feet and less than 2 inches in diameter at groundline are the only ones that have a good chance of recruitment into the overstory (Sander 1972).

The amount of seedling sprouts found in forests can vary greatly. Dieback in oak reproduction occurs in populations that display high physiological, morphological, and genetic variability. In such populations, soil moisture, nutrient availability, and light conditions create microclimates and seedling sprouts are often found in homogenous groups (Hodges and Gardiner 1992). While oaks have the physiological predisposition to develop and thrive as seedling sprouts, environmental conditions ultimately drive their success.

Repeated shoot dieback and consequent resprouting is believed to be an important aspect of the evolutionary development and adaptive strategy of oaks (Johnson 1992). While the proliferation of this strategy varies among individual species and sites, it is undoubtedly an adaptation that can provide advantages after periods of unfavorable conditions. On good sites, oak seedlings that have not experienced shoot dieback grow more slowly than rival species, often 
become outcompeted, and are soon shaded out by the newly developing understory. The ability to repeatedly resprout, and come back stronger every time, allows oaks to respond to natural disturbances or thrive on xeric sites.

Sprouts originating from cut trees larger than 2 inches DBH are referred to as stump sprouts. Sprouts arising from large preexisting root systems that have no aboveground stump are referred to as grubs. Grubs are common in areas where perpetual above ground disturbances such as recurring fires destroy stumps and at the same time retain high light levels by maintaining low overstory density. In oak savannas, grubs may recurrently die back and resprout attaining ages of several hundred years. Stump sprouts and grubs, as well as seedling sprouts, originate from dormant buds at or near the root collar. Buds remain just below the bark and are connected to the pith of the parent tree through bud traces that elongate annually with each growth ring. When buds break dormancy after the parent stem is lost, resistance to bark thickness can inhibit sprout establishment (Johnson and Shifley 2002). Buds are multiplied by branching off existing ones this occurs more vigorously in young stems, while aging buds experience increasing mortality. The physical bark barrier, along with altering rates of bud branching and mortality, lead to a decrease in the ability to produce sprouts as trees age and grow in diameter (Johnson 1977). Stump sprouts and grubs can account for a large percentage in recruitment of some stands because of their reliance on well developed root systems.

While dry conditions discourage the direct success of seedlings and favor reproduction through sprouts, oak forests on xeric sites are seldom successionally displaced by other species (Johnson 1992). Oak studies that have investigated the success of oak stand replacement by oaks emphasize the importance of an accumulation of advanced reproduction with high root:shoot ratios (Carvell and Tryon 1961, Johnson 1992) and consequent timely release of the 
regeneration. The actual development of this ratio, however, is not easily or practically

assessable in living forest trees. Conditions that favor a high ratio, such as repeated disturbances including fire, can be more easily monitored and manipulated.

\section{Regeneration Assessment Background}

By itself, the number of oak seedlings is not a good indicator of future oak overstory percentage. Density and size of seedlings and sprouts, as well as the sprouting potential of larger oak stems, must also be considered (Sander et al. 1984, Belli et al. 1999). Different approaches have been taken to estimate future oak stocking based on pre-harvest advanced regeneration.

Sander et al. (1984) developed a guide for the central hardwood region to evaluate oak regeneration in even-aged oak stands. Stands were assessed as adequate or inadequate to produce $30 \%$ oak stocking (dominant or codominant oaks) 20 years after a clearcut. Factors taken into consideration include aspect, relative slope position, height and groundline diameter of seedlings, and stump sprouting potential of overstory oaks. The guide assigns a stocking value to each tallied seedling, with higher values for taller seedlings. If seedling abundance falls short of the 30\% stocking mark, Sander et al. (1984) suggested calculating the number of stumps necessary to compensate for the shortcoming. Thus, rather than calculating total projected stocking based on seedlings and sprouts, this method calculates stocking based on seedlings and minimum number of sprouts necessary to reach a stocking of at least $30 \%$. This method is a useful tool for foresters who wish to evaluate their regeneration potential in terms of adequacy or inadequacy in achieving a $30 \%$ oak stocking over a 20 -year growth period following complete harvest.

In southern bottomland oak forests, Johnson (1980) and Belli et al. (1999) assigned point values to oak regeneration based on height to describe the potential of oak seedlings and sprouts 
to produce at least one stem in a "free-to-grow" competitive position on a 1/100 acre plot after three growing seasons. Johnson (1980) stated his assessment of the seedling plots as adequately ( $\geq 12$ points) or insufficiently stocked. Belli et al. (1999) made adjustments to predict the actual probability of oak stocking rather than using a threshold value.

In south central Pennsylvania, Steiner et al. (2008) used a pre-harvest oak regeneration inventory to estimate total oak stocking percentage in the third decade after clear-cutting. By tallying oak seedlings in seven height classes and multiplying the amount by height class factors (where larger seedlings are more heavily weighted), an aggregate oak seedling height was calculated for each of the sample 1/1000 acre plots. In order to predict future stocking by stump sprouts, DBH classes of all oaks > 2 inches in 1/20 acre plots are tallied by species. After calculating mean tree density for each diameter class, the density is multiplied by a stocking factor specific to species and diameter class. The sum of seedling and stump sprout probabilities reflects the expected percentage of oak in the intermediate to dominant crown classes in the third decade after complete harvest.

Compared to the method of Sander et al. (1984), this method by Steiner et al. (2008) does not just qualitatively evaluate the regeneration in terms of reaching a certain stocking goal but offers a way to quantify and compare potential across stands. Unlike Johnson (1980), it assesses the potential based on actual probability. This method evaluates the heights of seedling sprouts as well as the sprouting potential of mid- and overstory trees more discriminately than the system by Belli et al. (1999). 


\section{The Oak-Fire Relationship}

Great effort has been dedicated to shedding light on the oak-fire relationship. Oaks are of diverse value to managers throughout the Appalachians ranging from timber and wildlife mast production to 'natural' stand creation. Concerns have been raised regarding the problem of recruiting sufficient amounts of oaks into overstory strata (Smith 1992) resulting in oak stands that are replaced by other, more shade tolerant species (Nowacki and Abrams 2008).

While there have been recorded shifts in ecosystems and individual species over periods of several thousands of years following the receding of the glaciers after the peak of the Wisconsin glaciation (18,000 years ago) (Brose et al. 2001), forest composition and dynamics are believed to be relatively stable over shorter time spans of 500-2000 years (Lorimer 2001). Paleoecological studies suggest that oak-dominated forests established during the warmer and dryer Holocene epoch (beginning about 10,000 years ago) during which incidences of lightningcaused fire were more frequent (Van Lear and Waldrop 1989, Abrams 1992). Also, Native Americans have been occupying the continent since at least 12,000 years ago. As populations grew and spread across North America, these people used frequent, low intensity fires to modify the eastern forests to create open woodlands for easier hunting, gathering, travel, and a variety of other uses (Van Lear and Waldrop 1989, Brose et al. 2001). While it is difficult to discriminate between fires of anthropogenic origin and those of other causes (Lorimer 2001), it can be argued that the resulting disturbance regime existed long enough, and by a people living sustainably off the land, to be considered "natural". Regardless, it is evident that the Native American use of fire effectively altered the landscape and created a heterogeneous mosaic of different vegetation types, some of which included fire-adapted species such as oaks (Delcourt and Delcourt 1997). 
The modern-day, oak dominated eastern hardwood forest is believed to have been in place for the past 4,000 years (Delcourt and Delcourt 1997, Brose et al. 2001).

Oak succession can be severely impacted by long-term changes in fire disturbance regimes. In the Southern Appalachians, the increased arrival of European settlers in the 1800s did not at first significantly alter the disturbance regime, as Europeans readily adopted Native burning practices. However, during the late 1800s and early 1900s, commercial timber harvesting effectively stripped large landscapes of its timber. The remaining slash created an immense fuel source and the technology that enabled the logging in the first place - steam powered facilities and transports - often delivered the igniting spark resulting in vast, devastating wildfires (Van Lear and Waldrop 1989, Brose et al. 2001). By the 1920s, the newly established U.S. Forest Service had embarked on a mission to eradicate these wildfires by building hundreds of fire towers and passing legislation prohibiting the burning of forests (Van Lear and Waldrop 1989). The very successfully launched Smokey the Bear campaign of 1944 established an antifire mentality that rang in an era of fire suppression in the eastern forests. In the absence of fire, high-quality hardwood forests developed throughout the region (Brose et al. 2001).

Ecologically, the prolonged period of fire absence has lead to the spread of fire sensitive, shade tolerant species such as red maple (Acer rubrum L.) at the cost of species such as oak that were dominant in the previous frequent, low-intensity fire regimes. Nowacki and Abrams (2008) coined the term "mesophication" for the positive feedback cycle of creating ever moister, cooler microclimates beneath dense stands of shade tolerant species that are less prone to fire and enable only more mesophytic regeneration to survive. Without repeated fires, oak forests on mesic sites bear all the characteristics of early to mid-successional systems. Oaks may act as late 
succession communities only on xeric sites where competitive pressure by other species is low (Abrams 1992).

Carvell and Tryon (1961) found that although oaks are often associated with drier sites such as south-facing slopes and ridges, the amount and degree of disturbance - including fire show closer correlation with total oak regeneration than other independent variables including aspect, exposure, and slope position. The greater the past disturbance, the more oak regeneration is present. When the factors of sunlight and disturbance are combined, an even higher correlation with density and height of regeneration was observed, implying that oak seedlings can persist not only on xeric sites but can be established and maintained on more mesic sites if adequate sunlight consistently reaches the forest floor. Fires can thus have a doubled influence by creating a xeric environment and by creating high light conditions when killing the over- and midstories (Carvell and Tryon (1961).

Most oak forests appear to rely on fire for their perpetuation; it is, however, the repetition of fire occurrence that seems to be the primary factor. Burning provides a fresh dose of available nutrients to seedlings as seen in significantly greater concentrations of nitrogen, phosphorous, potassium, and magnesium in foliage. More importantly, the increased light availability associated with the mortality of some understory vegetation following fire events leads to higher photosynthetic potential and greater growth rates of diameter and height. However, these fireinduced growth spurts can also be observed in seedlings of non-oak species with even higher growth rates. Single prescribed fires do not seem to significantly improve the status of oak regeneration in forests (Gilbert et al. 2003).

Repeated burns every two years, on the other hand, have the potential to successfully limit the regeneration of shade tolerant and fire intolerant species in favor of successful 
establishment of intermediate shade tolerant oak species. More shade intolerant oaks such as scarlet oak (Quercus coccinea Münchh.) may require even more frequent fire disturbance. Frequently burned stands in the Cumberland Plateau have higher percentages of oak in the overstory as well as in the understory as saplings (Arthur et al. 1998). Fire events favor oaks by affecting less fire-adapted species such as red maple, sassafras (Sassafras albidum (Nutt.) Nees) and black birch (Betula lenta L.) through higher fire-related injuries and mortality (Copenheaver et al. 2006). This reduction of small fire-intolerant species opens up more growing space for oaks (Signell et al. 2005). While the shade cast by understory vegetation can be considerable (Lorimer et al. 1994), advance oak regeneration is stimulated most when repeated fire events are intense enough to reduce both overstory and understory density (Signell et al. 2005). 


\section{METHODS}

Study Area

Cabwaylingo State Forest (CSF) is located in Wayne County, in southwestern West Virginia (Figure 1). It derives its name from the surrounding counties it was intended to serve: Cabell, Wayne, Lincoln, and Mingo. The 8,150 acre State Forest started in 1933 with the acquisition of 6,196 acres that were quickly added to by additional land purchases by the state. Original land cover was predominantly farmland and farm woodlot. In 1935 the Civilian Conservation Corps (CCC) set up Camp Twelvepole (also known as Aracoma) in Mingo County and started efforts for stream and stand improvement, fire control, raising log cabins for recreational use, and establishing several hiking trails. Two early multiple-use forest management harvests were conducted at Turkey Creek (1956) and Gourd Branch (1960) before the development of a management plan in 1970. Under this management plan, seven additional 50-330 acre harvests followed, removing an average of just under 4,000 board feet per acre per harvest in order to achieve wildlife habitat improvement, timber improvement, and recreational appeal (West Virginia Division of Forestry 2001).

Approximately one-half of all forested areas of West Virginia are comprised of mixed oak types. In mesic bottomlands, white oak (Quercus alba L.) and northern red oak are mixed with yellow-poplar; lower and mid-slopes are dominated by an aggregation of white oak, black oak (Quercus velutina Lam.), and northern red oak; the xeric environments of upper slopes and ridges are characterized by white oak, chestnut oak, and scarlet oak (Carvell and Tryon 1961). In CSF these oaks are intermingled with other common hardwoods of the southern Appalachians such as red maple, sugar maple (Acer saccharum Marsh.), basswood (Tilia americana L.), and white ash (Fraxinus americana L.). 


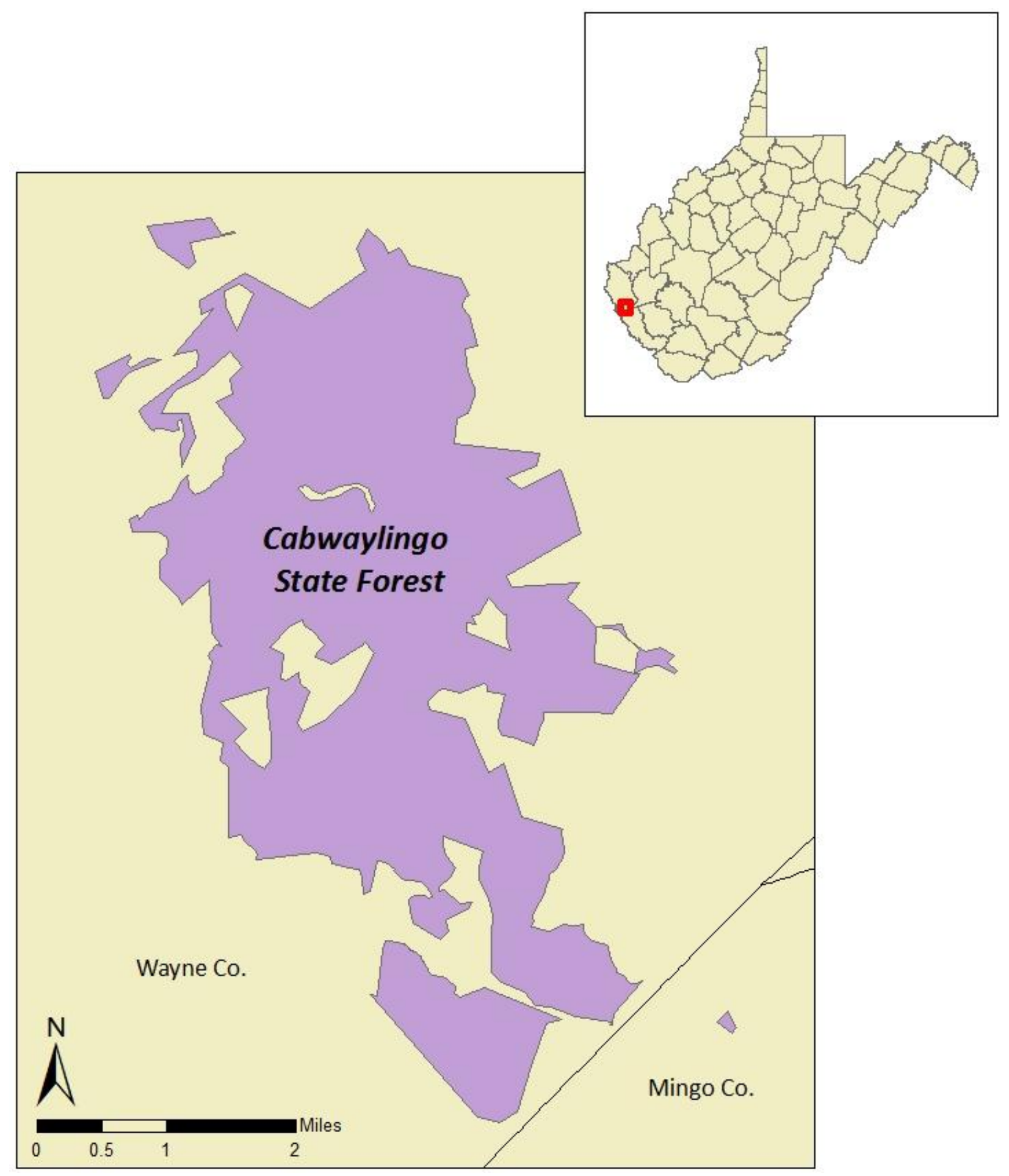

Figure 1 Location of Cabwaylingo State Forest in West Virginia. 


\section{Fire Map Creation}

To spatially quantify the recorded wildfires in CSF, fire reports kept by the West Virginia Division of Forestry Region 3 Milton office were consulted. Records dated from 1972 to 2008 and were categorized by season: spring fire season (January through June) and fall fire season (July through December). Fires greater than 5 acres in size were accompanied by hand-drawn maps, some of which were done on tracing paper, with major landmarks noted. Most fires greater than 50 acres were hand drawn - and after 2000 digitally superposed - onto copies of topographic maps with a scale of 1:24,000. Of the 68 fire reports, we used 43, discarding 25 either because fires were smaller than 5 acres or because reports had no spatial reference points.

To digitize fire locations we used ArcView 9.3 (ESRI 2003). All features were projected in the Universal Transverse Mercator (UTM) North American Datum of 1983 (NAD-83) at a scale of 1:24,000. Background topographic maps for the Wilsondale, Webb, Radnor, and Kiahsville quadrangles were obtained online from the West Virginia GIS Technical Center (2008). CSF boundaries are based on West Virginia Department of Natural Resources boundary shapefiles and recent land surveys. These background and boundary features, along with a point coordinate of probable ignition location noted on the fire reports, were used to identify the locations of the fires as sketched on the hard copies.

The individual fires were digitized by creating a new polygon shapefile in ArcCatalog. The ArcMap tools of the Editor Toolbar were then used to trace the outlines of the fires following significant landmarks and contour lines as indicated on the fire reports. Information such as date of fire, fire report identification number, and cause were also conserved as fields in the attribute table. 
After fires had been digitized, the Union geoprocessing command of the Arc GIS Toolbox was used to add the fires spatially. In the Union's Attribute Table, this addition was quantified by summing the value of all "Occurrence" fields of the individual fires (value=1), yielding the "Total Fire Occurrence" (values 1-6). The fire occurrences were then added to a "No Fire" ("Occurrence" value=0) CSF map. "Occurrence" values were assigned a cold to hot color pattern creating a map that shows the frequency of wildfires at any given location in CSF from 1972-2007 (Figure 2).

\section{Sample Point Locations}

Within these areas of different fire occurrences, sample points were created digitally. The digitization of sample plots followed a procedure similar to the creation of fire polygons; instead of polygons, the shapefile was created as a point vector. In order to sample similar forest cover types within these areas, a 1970 U.S. Forest Service timber management map depicting forest cover types in CSF was consulted to identify areas classified as oak/hickory (Carya spp.) stands (West Virginia Division of Forestry, Milton, WV office). Sampling was restricted to these stands.

Within the same fire occurrence areas, sample points were established making a conscious effort to cover a variety of aspects and four elevations $(\leq 1,100 \mathrm{ft} ; 1,101-1,200 \mathrm{ft} ; 1,201$ $1,300 \mathrm{ft} ;>1,300 \mathrm{ft})$. In this manner, 164 sample locations in seven different fire event areas were determined (Figure 3, Table 1). 


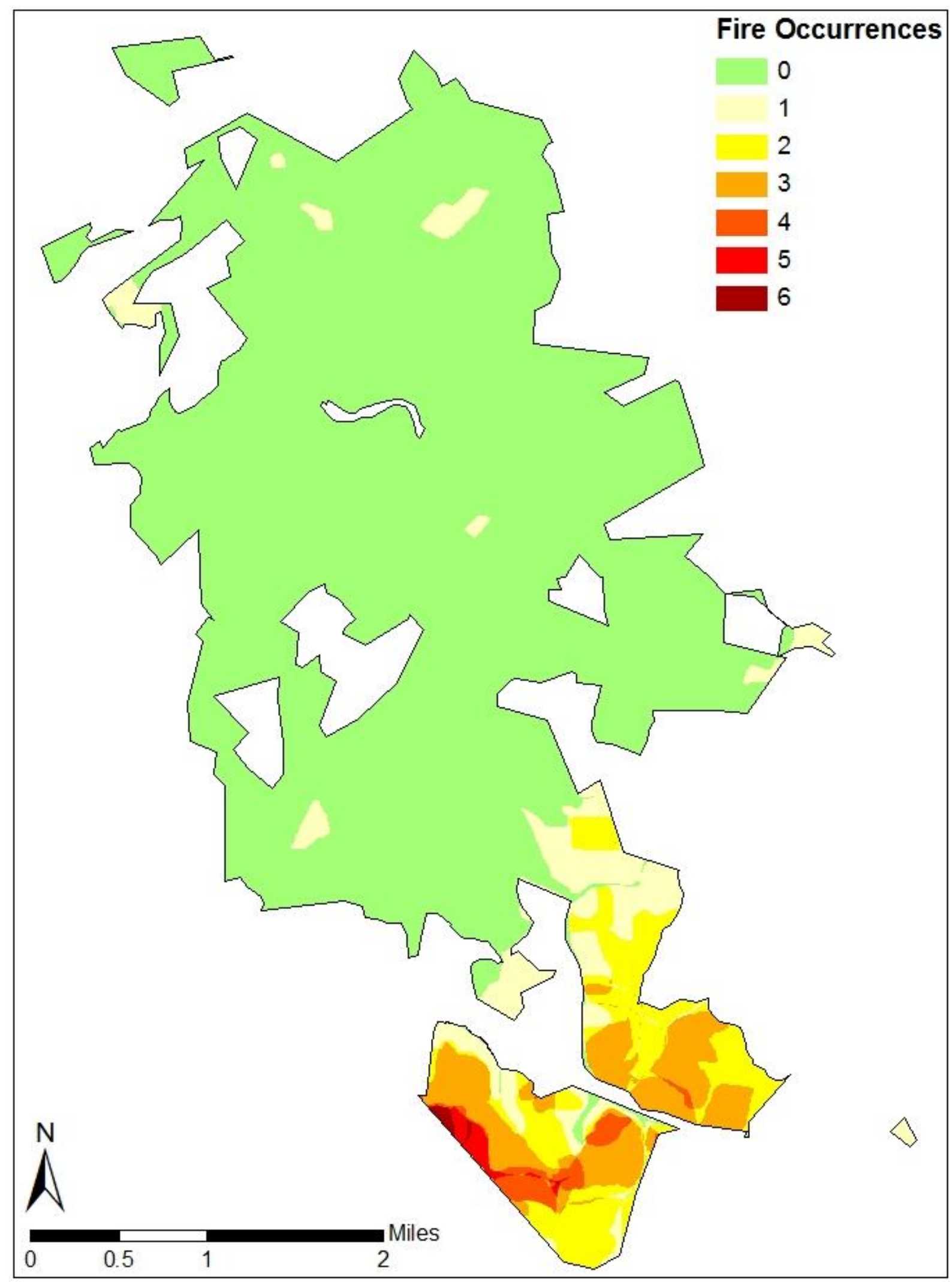

Figure 2 Fire occurrences in Cabwaylingo State Forest 1972-2007. 


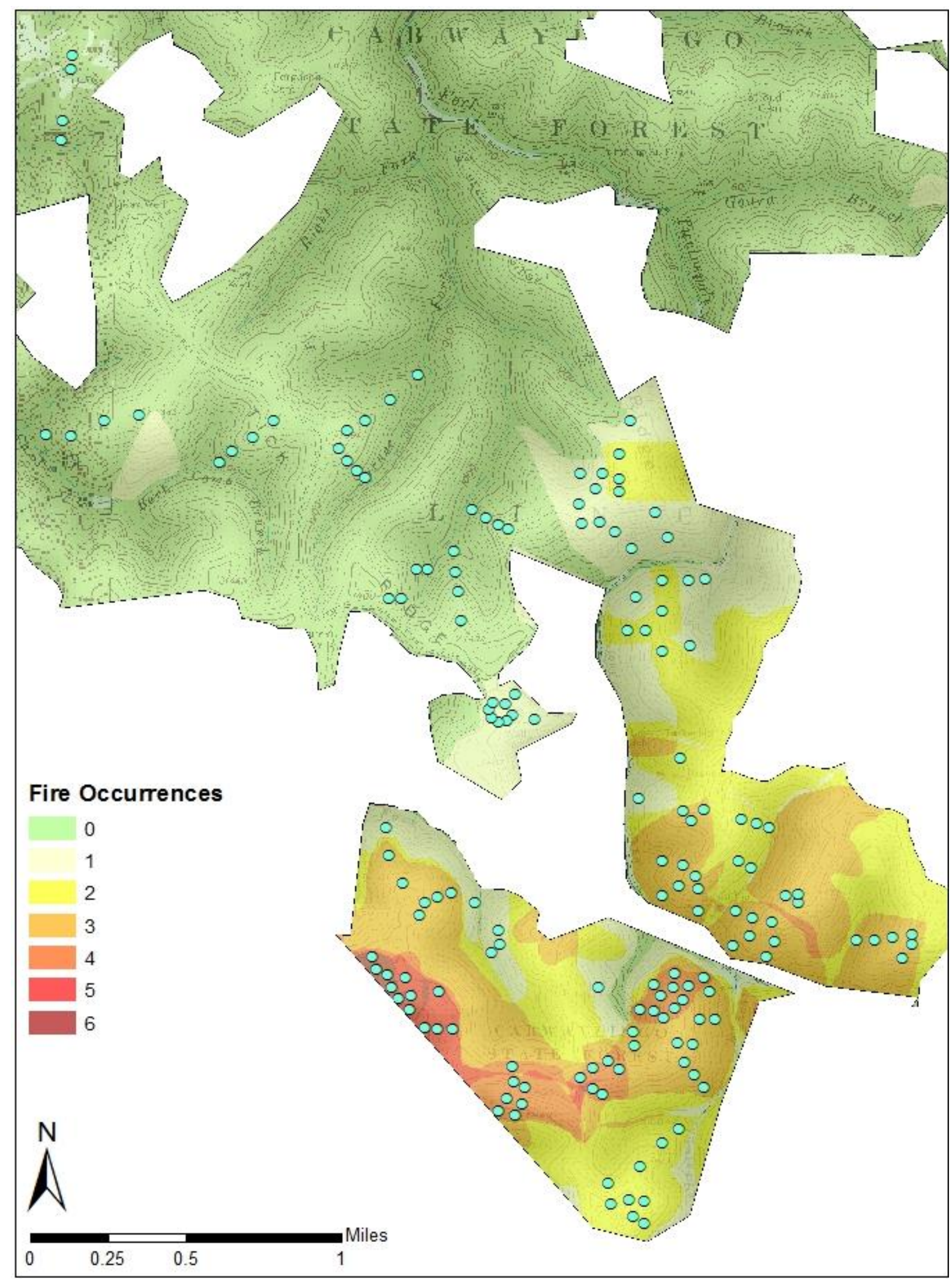

Figure 3 Sample point locations in Cabwaylingo State Forest. 
Table 1 Physical summary of sample point locations at Cabwaylingo State Forest.

\begin{tabular}{|c|c|c|c|}
\hline $\begin{array}{c}\text { Fire } \\
\text { Occurrences }\end{array}$ & $\begin{array}{c}\text { Number of } \\
\text { Sample Points }\end{array}$ & $\begin{array}{c}\text { Sample Point } \\
\text { Elevation Range (ft) }\end{array}$ & Aspects Covered by Sample Points \\
\hline 0 & 32 & $938-1417$ & $\mathrm{~N}(4), \mathrm{NE}(4), \mathrm{E}(4), \mathrm{SE}(4), \mathrm{S}(4), \mathrm{SW}(4), \mathrm{W}(4), \mathrm{NW}(4)$ \\
\hline 1 & 31 & $922-1444$ & $\mathrm{~N}(4), \mathrm{NE}(4), \mathrm{E}(4), \mathrm{SE}(4), \mathrm{S}(4), \mathrm{SW}(3), \mathrm{W}(4), \mathrm{NW}(4)$ \\
\hline 2 & 23 & $997-1463$ & $\mathrm{~N}(4), \mathrm{NE}(4), \mathrm{E}(4), \mathrm{SE}(4), \mathrm{S}(0), \mathrm{SW}(2), \mathrm{W}(3), \mathrm{NW}(2)$ \\
\hline 3 & 42 & $961-1424$ & $\mathrm{~N}(4), \mathrm{NE}(4), \mathrm{E}(4), \mathrm{SE}(4), \mathrm{S}(8), \mathrm{SW}(7), \mathrm{W}(5), \mathrm{NW}(6)$ \\
\hline 4 & 24 & $1043-1480$ & $\mathrm{~N}(3), \mathrm{NE}(4), \mathrm{E}(2), \mathrm{SE}(3), \mathrm{S}(3), \mathrm{SW}(3), \mathrm{W}(3), \mathrm{NW}(3)$ \\
\hline 5 & 7 & $1125-1447$ & $\mathrm{~N}(0), \mathrm{NE}(0), \mathrm{E}(0), \mathrm{SE}(0), \mathrm{S}(3), \mathrm{SW}(1), \mathrm{W}(3), \mathrm{NW}(0)$ \\
\hline 6 & 5 & $1273-1378$ & $\mathrm{~N}(0), \mathrm{NE}(0), \mathrm{E}(0), \mathrm{SE}(2), \mathrm{S}(1), \mathrm{SW}(1), \mathrm{W}(1), \mathrm{NW}(0)$ \\
\hline
\end{tabular}




\section{Data Collection}

Field data was collected between May and August of 2008. The predetermined sample point locations were transferred to a Garmin eTrex Legend HCx handheld GPS unit for navigation. With WAAS enabled an accuracy of 15 feet. At each point, a plot center was established and four different types of plots were measured.

First, a basal area factor (BAF) 20 prism was used to tally all living trees $\geq 2$ inches DBH. Species and DBH of all "in-trees" were recorded. In order to gain insight into the impact wildfires have on sawtimber volume and value, a merchantable height measurement was taken (using a TruPulse 200) of all trees with DBH > 11.5 and a total height measurement of those trees that had evidence of fire scars or scars due to rot. Height of the defect in the trunk was also approximated and its percentage of the log section roughly estimated (25, 50, 75, or $100 \%)$.

Second, sapling plots with an $11.8 \mathrm{ft}$ radius (1/100 acre) were established around the same prism plot center. All living stems $\geq 5 \mathrm{ft}$ but $<2$ inches DBH were recorded by species and DBH.

Third, three seedling plots were measured. From the prism point center we paced off $30 \mathrm{ft}$ at bearings of $0^{\circ}, 120^{\circ}$, and $240^{\circ}$. At each of the newly established centers, all seedlings (stems $<5 \mathrm{ft}$, $<2$ inches diameter at base) were recorded by species within a radius of $3.7 \mathrm{ft}(1 / 1000$ acre). All oak seedlings were recorded by height classes $(<1.0,1.0-1.5,1.6-2.5,2.6-3.5,3.6-4.5$, and 4.5-5.0 ft).

Finally, to estimate oak regeneration potential (Steiner et al. 2008), oaks in a radius of $26.3 \mathrm{ft}$ (1/20 acre) from the prism plot center were recorded by group (chestnut oak; scarlet, northern, and southern red oaks (Quercus falcata Michx.); black oak; and white oak) and diameter classes (2-6, 7-10, 11-14, 15-18, 19-22, 23-26, 27-30, 31-34, and >34 inches). 


\section{Data Analysis}

Using the prism plots" "in-trees", we calculated basal area per acre (BA/ac in $\left.\mathrm{ft}^{2}\right)$ and trees per acre (TPA) for each plot and the treatment means thereof for each of the fire occurrences. Percentages of these values made up of oaks and non-oaks were also summed for comparison. For volume assessment, the DBH and number of 16-foot sawlogs within each merchantable height bole were used to calculate International 1/4 -Inch Board Foot gross volume. For individual trees, the recorded cull height and percentage of the affected bole section that was estimated to be compromised due to defect were used to calculate total percentage of the bole lost (John Brooks, Division of Forestry and Natural Resources, West Virginia University, personal communication). By subtraction, the mean net volume per acre was then found for the different wildfire treatments. The gross, lost, and net volumes were used to estimate monetary stumpage values using June 2009 species specific timber prices (Appalachian Hardwood Center 2009).

An upland oak stocking chart was used to evaluate stocking in CSF based on the means of basal area and tree density for each wildfire treatment (Gingrich 1967). Based on the actual oak and total stand stocking percentages, we calculated an oak stocking percentage adjusted to full $(100 \%)$ stocking by dividing the actual oak stocking by the total stocking percentage.

Mean sapling and seedling density per acre was calculated for each of the different fire occurrences. In addition to density, for all oak seedlings, individuals were multiplied by the coefficient corresponding to their height classes $(0.5,1,2,3,4,5$, respectively) and then summed to calculate sample plot aggregate height $(\mathrm{AH})$. The means of these values by burn frequency were recorded as well as the corresponding means of plot stocking percentages (Equation 1).

Equation $1 \quad$ Plot Stocking Value (in percent) $=100 *\left(1-e^{-0.0973 * A H}\right)$ 
Analysis for oak seedling aggregate height was conducted using a square root transformation to normalize its residuals.

Statistical comparison of all means - including trees per acre, basal area per acre, sapling density per acre, seedling density per acre, lost board foot volume per acre, and net board foot volume per acre - was conducted by analysis of variance (ANOVA) of fire occurrence means. Means with a significant F-statistic (at $\alpha=0.05$ ) were compared using least square means (LSM). All statistical analyses were performed using SAS (2004). We followed the method by Steiner et al. (2008) and summed stocking projected from seedling and stump sprout origin to estimate total projected stocking percentage for each wildfire regime. Because we followed their method of tallying potential sprout producing trees we were not able to use ANOVA to compare stump sprout origin stocking, as all oaks within the same fire occurrence groups were tallied on the same spreadsheet thus making variation among plots within each treatment untraceable. 


\section{RESULTS}

The wildfires in Cabwaylingo have created dramatically different-looking forest stands (Table 2). Average total tree density of overstory trees is highest in areas that have burned three times or less (186-243 TPA). Greater fire occurrence reduced the overstory density in areas of four to six burns (38-151 TPA). Although no statistically significant differences were detected, there is a general negative trend in total tree density with increasing fire frequency. When the total tree density, however, is broken down by species, it becomes apparent that this negative trend is particularly characteristic of non-oak species. For example, mean non-oak densities ranged from 178 TPA in the unburned stands to only 19 TPA in the areas burned six times $(\mathrm{p}=0.0580)$. The most abundant non-oak overstory species include red maple, hickory, and blackgum (Nyssa sylvatica Marsh.). Overstory oak density, on the other hand, is highest in areas of three and four wildfires (153 and 96 TPA, respectively). The oak density after three burns (153 TPA) is significantly higher $(\mathrm{p}=0.0306)$ than the oak density of areas that have experienced six fires (20 TPA). Plots that have a history of more than three fires - with the exception of the 5 burn areas - hold more than half (51-64\%) of their overstory densities in oaks while less burned plots have only $26-34 \%$ in oaks.

Total basal area of overstory trees across wildfire occurrences shows a significantly decreasing trend $\left(121-52 \mathrm{ft}^{2} / \mathrm{ac} ; \mathrm{p}=0.001\right)$ with increasing fire frequency (Table 3$)$. This trend is especially pronounced among non-oaks. Once-burned areas have a mean non-oak basal area of $61 \mathrm{ft}^{2} / \mathrm{ac}$ while areas burned six times have only $16 \mathrm{ft}^{2} / \mathrm{ac}(\mathrm{p}=0.005)$. Oak basal area does not vary significantly $(\mathrm{p}=0.7579)$ with increasing fire frequency $\left(36-68 \mathrm{ft}^{2} / \mathrm{ac}\right)$. The basal area of oak species makes up between 50-70\% of total basal area across fire frequencies. 
Table 2 Mean overstory density per acre (TPA) of living trees $\geq 2$ inches DBH in Cabwaylingo State Forest.

Wildfire Occurrence

\begin{tabular}{|c|c|c|c|c|c|c|c|c|}
\hline & \multicolumn{7}{|c|}{ 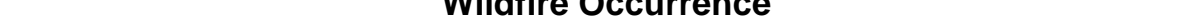 } & \multirow{2}{*}{ p-value } \\
\hline & 0 & 1 & 2 & 3 & 4 & 5 & 6 & \\
\hline Total & 242.86 & 228.01 & 185.55 & 237.65 & 150.85 & 141.31 & 38.46 & 0.3042 \\
\hline Oaks & $64.79^{a b}$ & $59.77^{\mathrm{ab}}$ & $64.69^{a b}$ & $152.83^{a}$ & $96.33^{a b}$ & $37.77^{a b}$ & $19.56^{b}$ & 0.0306 \\
\hline White Oaks & 43.60 & 50.01 & 57.77 & 115.54 & 79.14 & 26.45 & 10.22 & \\
\hline Quercus alba & 13.65 & 19.06 & 19.60 & 30.35 & 3.02 & 11.78 & 3.59 & \\
\hline Quercus prinus & 29.95 & 30.95 & 38.17 & 85.19 & 76.12 & 14.66 & 6.63 & \\
\hline Red Oaks & 21.19 & 9.77 & 6.92 & 37.29 & 17.19 & 11.32 & 9.34 & \\
\hline Quercus coccinea & 0.00 & 0.00 & 0.23 & 0.00 & 0.00 & 0.00 & 0.00 & \\
\hline Quercus falcata & 10.54 & 4.39 & 0.00 & 3.01 & 5.80 & 0.00 & 3.09 & \\
\hline Quercus rubra & 3.29 & 0.76 & 1.92 & 8.41 & 2.67 & 2.13 & 4.08 & \\
\hline Quercus velutina & 7.37 & 4.62 & 4.77 & 25.88 & 8.73 & 9.20 & 2.17 & \\
\hline Non-Oaks & 178.07 & 168.24 & 120.86 & 84.82 & 54.52 & 103.54 & 18.90 & 0.0580 \\
\hline Acer rubrum & 70.99 & 64.74 & 54.91 & 54.43 & 4.39 & 47.93 & 0.00 & \\
\hline Acer saccharum & 16.93 & 3.59 & 5.67 & 0.00 & 0.00 & 0.00 & 0.00 & \\
\hline Betula lenta & 0.00 & 6.85 & 14.64 & 0.00 & 0.00 & 0.00 & 0.00 & \\
\hline Carya spp. & 17.64 & 21.35 & 22.66 & 8.46 & 2.49 & 4.45 & 18.90 & \\
\hline Cercis canadensis & 0.00 & 0.00 & 0.00 & 0.00 & 4.24 & 0.00 & 0.00 & \\
\hline Cornus florida & 0.00 & 0.00 & 5.27 & 0.00 & 0.00 & 0.00 & 0.00 & \\
\hline Fagus grandifolia & 8.84 & 9.83 & 0.00 & 1.75 & 0.00 & 0.00 & 0.00 & \\
\hline Fraxinus spp. & 0.00 & 1.21 & 0.00 & 0.00 & 0.00 & 0.00 & 0.00 & \\
\hline Juglans nigra & 1.51 & 0.00 & 0.00 & 0.00 & 0.00 & 0.00 & 0.00 & \\
\hline Liriodendron tulipifera & 9.22 & 7.44 & 4.20 & 7.94 & 7.35 & 0.00 & 0.00 & \\
\hline Magnolia acuminata & 0.00 & 2.65 & 5.24 & 0.31 & 2.88 & 0.00 & 0.00 & \\
\hline Nyssa sylvatica & 36.63 & 32.28 & 3.43 & 9.96 & 10.56 & 0.00 & 0.00 & \\
\hline Ostrya virginiana & 0.00 & 0.89 & 0.00 & 0.00 & 0.00 & 0.00 & 0.00 & \\
\hline Oxydendrum arboreum & 8.76 & 0.00 & 1.25 & 0.00 & 0.00 & 0.00 & 0.00 & \\
\hline Pinus echinata & 0.00 & 3.59 & 0.00 & 0.00 & 1.66 & 0.00 & 0.00 & \\
\hline Pinus rigida & 0.00 & 0.21 & 0.00 & 0.00 & 1.68 & 0.00 & 0.00 & \\
\hline Pinus strobus & 0.00 & 0.24 & 0.00 & 0.00 & 0.00 & 0.00 & 0.00 & \\
\hline Pinus virginiana & 0.00 & 5.59 & 0.00 & 0.64 & 1.06 & 0.00 & 0.00 & \\
\hline Robinia pseudoacacia & 1.55 & 1.95 & 1.38 & 0.00 & 0.00 & 51.16 & 0.00 & \\
\hline Sassafras albidum & 0.00 & 0.00 & 2.21 & 0.00 & 14.05 & 0.00 & 0.00 & \\
\hline Tilia americana & 0.00 & 5.80 & 0.00 & 1.32 & 4.17 & 0.00 & 0.00 & \\
\hline Tsuga canadensis & 5.99 & 0.00 & 0.00 & 0.00 & 0.00 & 0.00 & 0.00 & \\
\hline
\end{tabular}

${ }^{\text {a }}$ Means with the same letters per row show no statistically significant difference $(\alpha=0.05)$. 
Table 3 Mean overstory basal area per acre $\left(\mathrm{ft}^{2} / \mathrm{ac}\right)$ of living trees $\geq 2$ inches DBH in Cabwaylingo State Forest.

Wildfire Occurrence

\begin{tabular}{|c|c|c|c|c|c|c|c|c|}
\hline & 0 & 1 & 2 & 3 & 4 & 5 & 6 & p-value \\
\hline Total & $117.50^{a}$ & $121.29^{a}$ & $103.48^{a b}$ & $96.67^{a b}$ & $76.67^{a b}$ & $68.57^{\mathrm{ab}}$ & $52.00^{b}$ & 0.0001 \\
\hline Oaks & 67.50 & 60.00 & 65.22 & 66.19 & 53.33 & 51.43 & 36.00 & 0.7579 \\
\hline White Oaks & 48.13 & 52.26 & 53.04 & 44.76 & 34.17 & 37.14 & 16.00 & \\
\hline Quercus alba & 13.13 & 25.16 & 23.48 & 10.00 & 3.33 & 14.29 & 4.00 & \\
\hline Quercus prinus & 35.00 & 27.10 & 29.57 & 34.76 & 30.83 & 22.86 & 12.00 & \\
\hline Red Oaks & 19.38 & 7.74 & 12.17 & 21.43 & 19.17 & 14.29 & 20.00 & \\
\hline Quercus coccinea & 0.00 & 0.00 & 0.87 & 0.00 & 0.00 & 0.00 & 0.00 & \\
\hline Quercus falcata & 8.75 & 1.94 & 0.00 & 3.33 & 3.33 & 0.00 & 8.00 & \\
\hline Quercus rubra & 3.75 & 1.29 & 3.48 & 3.81 & 3.33 & 2.86 & 8.00 & \\
\hline Quercus velutina & 6.88 & 4.52 & 7.83 & 14.29 & 12.50 & 11.43 & 4.00 & \\
\hline Non-Oaks & $50.00^{a}$ & $61.29^{a}$ & $38.26^{\mathrm{ab}}$ & $30.48^{a b}$ & $23.33^{a b}$ & $17.14^{b}$ & $16.00^{b}$ & 0.0005 \\
\hline Acer rubrum & 12.50 & 12.90 & 10.43 & 8.10 & 0.83 & 8.57 & 0.00 & \\
\hline Acer saccharum & 3.75 & 3.87 & 1.74 & 0.00 & 0.00 & 0.00 & 0.00 & \\
\hline Betula lenta & 0.00 & 1.94 & 0.87 & 0.00 & 0.00 & 0.00 & 0.00 & \\
\hline Carya spp. & 8.75 & 9.03 & 8.70 & 5.71 & 2.50 & 5.71 & 16.00 & \\
\hline Cercis canadensis & 0.00 & 0.00 & 0.00 & 0.00 & 0.83 & 0.00 & 0.00 & \\
\hline Cornus florida & 0.00 & 0.00 & 0.87 & 0.00 & 0.00 & 0.00 & 0.00 & \\
\hline Fagus grandifolia & 5.63 & 2.58 & 0.00 & 1.43 & 0.00 & 0.00 & 0.00 & \\
\hline Fraxinus spp. & 0.00 & 1.94 & 0.00 & 0.00 & 0.00 & 0.00 & 0.00 & \\
\hline Juglans nigra & 0.63 & 0.00 & 0.00 & 0.00 & 0.00 & 0.00 & 0.00 & \\
\hline Liriodendron tulipifera & 9.38 & 12.26 & 6.09 & 10.95 & 6.67 & 0.00 & 0.00 & \\
\hline Magnolia acuminata & 0.00 & 1.29 & 4.35 & 0.48 & 1.67 & 0.00 & 0.00 & \\
\hline Nyssa sylvatica & 5.00 & 5.16 & 1.74 & 0.95 & 2.50 & 0.00 & 0.00 & \\
\hline Ostrya virginiana & 0.00 & 0.65 & 0.00 & 0.00 & 0.00 & 0.00 & 0.00 & \\
\hline Oxydendrum arboreum & 1.25 & 0.00 & 0.87 & 0.00 & 0.00 & 0.00 & 0.00 & \\
\hline Pinus echinata & 0.00 & 2.58 & 0.00 & 0.00 & 0.83 & 0.00 & 0.00 & \\
\hline Pinus rigida & 0.00 & 0.65 & 0.00 & 0.00 & 1.67 & 0.00 & 0.00 & \\
\hline Pinus strobus & 0.00 & 0.65 & 0.00 & 0.00 & 0.00 & 0.00 & 0.00 & \\
\hline Pinus virginiana & 0.00 & 1.29 & 0.00 & 0.48 & 1.67 & 0.00 & 0.00 & \\
\hline Robinia pseudoacacia & 0.63 & 1.94 & 1.74 & 0.00 & 0.00 & 2.86 & 0.00 & \\
\hline Sassafras albidum & 0.00 & 0.00 & 0.87 & 0.00 & 2.50 & 0.00 & 0.00 & \\
\hline Tilia americana & 0.00 & 2.58 & 0.00 & 2.38 & 1.67 & 0.00 & 0.00 & \\
\hline Tsuga canadensis & 2.50 & 0.00 & 0.00 & 0.00 & 0.00 & 0.00 & 0.00 & \\
\hline
\end{tabular}

${ }^{a}$ Means with the same letters per row show no statistically significant difference $(\alpha=0.05)$. 
Our results reveal that areas that have experienced three wildfires or less in the past 36 years have a comparatively high amount of trees in the lower diameter classes (Figure 4). The biggest shift is found in areas of two to four burns where oaks are more abundant in smaller than larger diameter classes. In these stands, oaks display a reverse-J curve and make up roughly half of the stems in any given diameter class. Oaks in areas of one or no fire generally have at least 5 TPA in the diameter classes between 4-20 inches. Oaks in areas that have been subject to five and six wildfires are absent from smaller DBH classes and restricted to the higher diameter classes of 12-20 inches. Interestingly, the TPA distribution of non-oaks followed a reverse Jcurve across diameter classes in all but the six burned sites.

Total sapling density is lowest in the unburned stands of CSF (766 stems/ac) and increases to 2817 stems/ac after six burns $(\mathrm{p}<0.0001)$ (Table 4). The occurrence of just one fire doubles the mean density. However, the number of oak saplings is highest ( 571 stems/ac) in areas of four wildfires $(\mathrm{p}=0.0004)$. Non-oak species also show a generally increasing trend $(\mathrm{p}=0.0002)$ across increasing fire frequencies. The percentage of oak saplings is highest (21\%) in areas of 4 burns while staying comparatively low in all other fire frequencies (2-9\%). The main competing species for oak saplings are red maple, blackgum, and sassafras; they outnumber oak saplings in all treatment classes. 

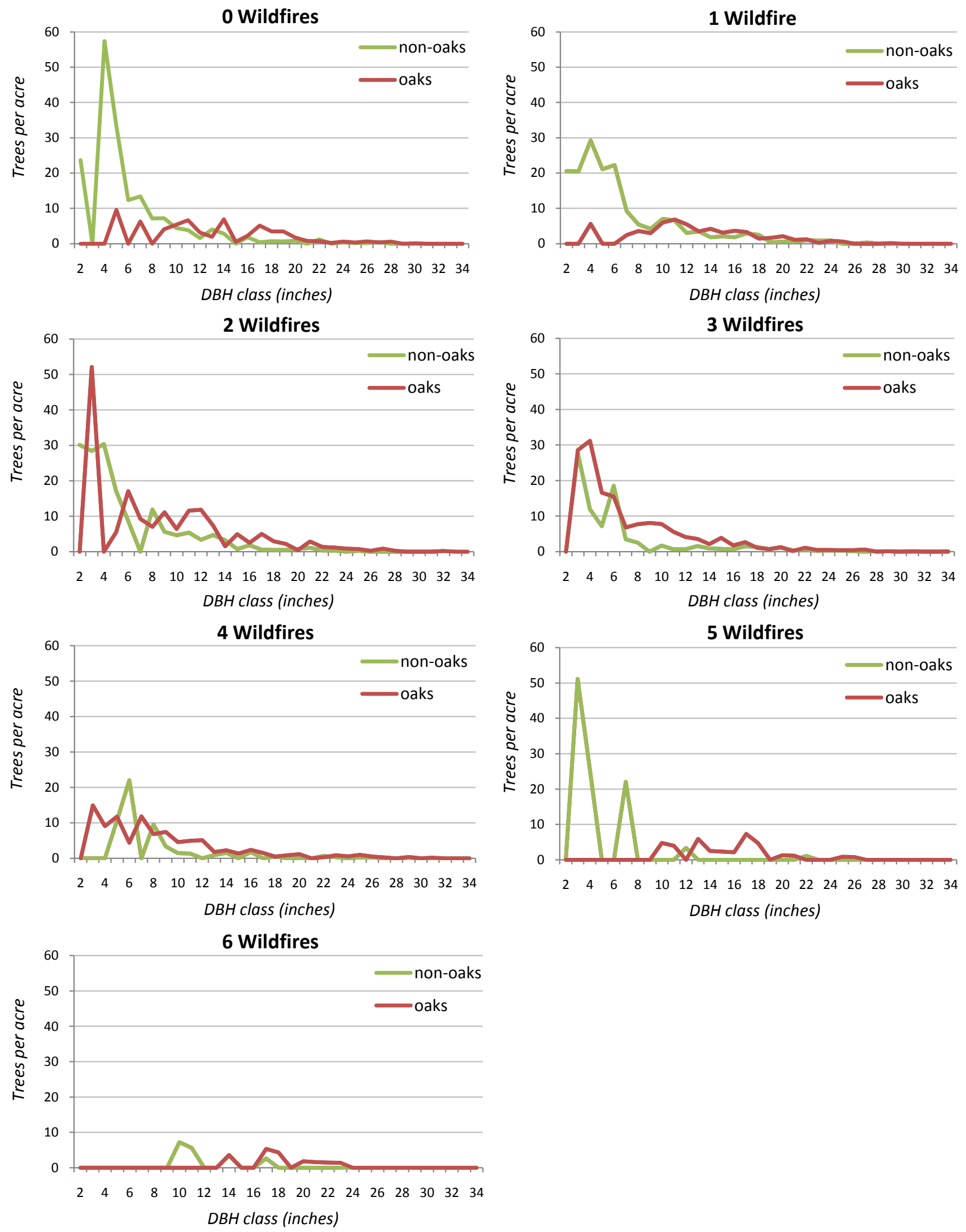

Figure 4 Size class distribution of overstory trees in Cabwaylingo State Forest. 
Table 4 Mean sapling density per acre of living stems $\geq 5 \mathrm{ft}$ tall and $<2$ inches DBH in Cabwaylingo State Forest.

Wildfire Occurrence

\begin{tabular}{|c|c|c|c|c|c|c|c|c|}
\hline & & \multirow{2}{*}{ p-value } \\
\hline & 0 & 1 & 2 & 3 & 4 & 5 & 6 & \\
\hline Total & $765.6^{a}$ & $1583.9^{\mathrm{ab}}$ & $2317.4^{\mathrm{bc}}$ & $1645.2^{\mathrm{ab}}$ & $2854.2^{c}$ & $2150.0^{b c}$ & $2816.7^{b c}$ & $<0.0001$ \\
\hline Oaks & $15.6^{\mathrm{a}}$ & $48.4^{\mathrm{a}}$ & $200.0^{a}$ & $128.6^{a}$ & $570.8^{b}$ & $116.7^{\mathrm{a}}$ & $50.0^{a}$ & 0.0004 \\
\hline White Oaks & 3.1 & 35.5 & 173.9 & 107.1 & 337.5 & 33.3 & 0.0 & \\
\hline Quercus alba & 3.1 & 3.2 & 8.7 & 57.1 & 0.0 & 0.0 & 0.0 & \\
\hline Quercus prinus & 0.0 & 32.3 & 165.2 & 50.0 & 337.5 & 33.3 & 0.0 & \\
\hline Red Oaks & 12.5 & 12.9 & 26.1 & 21.4 & 233.3 & 83.3 & 50.0 & \\
\hline Quercus falcata & 0.0 & 0.0 & 0.0 & 2.4 & 75.0 & 0.0 & 0.0 & \\
\hline Quercus rubra & 9.4 & 0.0 & 21.7 & 4.8 & 83.3 & 66.7 & 16.7 & \\
\hline Quercus velutina & 3.1 & 12.9 & 4.3 & 14.3 & 75.0 & 16.7 & 33.3 & \\
\hline Non-Oaks & $750.0^{a}$ & $1535.5^{\mathrm{ab}}$ & $2117.4^{b}$ & $1516.7^{\mathrm{a}}$ & $2283.3^{b}$ & $2033.3^{b}$ & $2766.7^{b}$ & 0.0002 \\
\hline Acer rubrum & 218.8 & 290.3 & 608.7 & 473.8 & 537.5 & 200.0 & 316.7 & \\
\hline Acer saccharum & 0.0 & 258.1 & 39.1 & 11.9 & 33.3 & 0.0 & 0.0 & \\
\hline Amelanchier spp. & 9.4 & 9.7 & 21.7 & 14.3 & 12.5 & 33.3 & 0.0 & \\
\hline Asimina triloba & 6.3 & 25.8 & 47.8 & 0.0 & 41.7 & 0.0 & 0.0 & \\
\hline Betula lenta & 0.0 & 12.9 & 0.0 & 0.0 & 0.0 & 0.0 & 0.0 & \\
\hline Carpinus caroliniana & 0.0 & 3.2 & 0.0 & 0.0 & 0.0 & 0.0 & 0.0 & \\
\hline Carya spp. & 12.5 & 45.2 & 73.9 & 76.2 & 137.5 & 166.7 & 100.0 & \\
\hline Castanea dentata & 0.0 & 3.2 & 21.7 & 0.0 & 20.8 & 0.0 & 0.0 & \\
\hline Cercis canadensis & 53.1 & 154.8 & 52.2 & 50.0 & 79.2 & 216.7 & 16.7 & \\
\hline Cornus florida & 9.4 & 45.2 & 17.4 & 31.0 & 25.0 & 83.3 & 0.0 & \\
\hline Fagus grandifolia & 225.0 & 103.2 & 91.3 & 81.0 & 100.0 & 0.0 & 0.0 & \\
\hline Fraxinus spp. & 0.0 & 12.9 & 13.0 & 9.5 & 8.3 & 0.0 & 0.0 & \\
\hline Juglans nigra & 0.0 & 0.0 & 0.0 & 2.4 & 0.0 & 0.0 & 0.0 & \\
\hline Kalmia latifolia & 9.4 & 3.2 & 4.3 & 11.9 & 0.0 & 0.0 & 0.0 & \\
\hline Liriodendron tulipifera & 0.0 & 35.5 & 65.2 & 4.8 & 8.3 & 0.0 & 0.0 & \\
\hline Magnolia acuminata & 0.0 & 0.0 & 8.7 & 0.0 & 0.0 & 0.0 & 0.0 & \\
\hline Nyssa sylvatica & 153.1 & 445.2 & 334.8 & 364.3 & 425.0 & 933.3 & 1166.7 & \\
\hline Ostrya virginiana & 0.0 & 3.2 & 13.0 & 4.8 & 0.0 & 0.0 & 0.0 & \\
\hline Oxydendrum arboreum & 21.9 & 25.8 & 117.4 & 66.7 & 154.2 & 16.7 & 116.7 & \\
\hline Rhododendron spp. & 0.0 & 0.0 & 4.3 & 0.0 & 0.0 & 0.0 & 0.0 & \\
\hline Rhus spp. & 0.0 & 0.0 & 56.5 & 2.4 & 62.5 & 66.7 & 50.0 & \\
\hline Robinia pseudoacacia & 0.0 & 12.9 & 91.3 & 11.9 & 141.7 & 150.0 & 133.3 & \\
\hline Sassafras albidum & 9.4 & 0.0 & 378.3 & 283.3 & 466.7 & 33.3 & 866.7 & \\
\hline Tilia americana & 3.1 & 22.6 & 4.3 & 4.8 & 12.5 & 0.0 & 0.0 & \\
\hline Tsuga canadensis & 9.4 & 0.0 & 0.0 & 0.0 & 0.0 & 0.0 & 0.0 & \\
\hline Ulmus spp. & 9.4 & 16.1 & 47.8 & 11.9 & 4.2 & 133.3 & 0.0 & \\
\hline Viburnum acerifolium & 0.0 & 6.5 & 4.3 & 0.0 & 0.0 & 0.0 & 0.0 & \\
\hline Unknown & 0.0 & 0.0 & 0.0 & 0.0 & 12.5 & 0.0 & 0.0 & \\
\hline
\end{tabular}

${ }^{a}$ Means with the same letters per row show no statistically significant difference $(\alpha=0.05)$. 
Means of total seedling density are relatively constant in all fire areas (15,841-20,753 seedlings/ac) with no statistical differences among fire occurrences $(\mathrm{p}=0.8411)$ (Table 5). The number of non-oak seedlings vary only slightly $(12,536-17,699$ seedlings/ac, $\mathrm{p}=0.6040)$. Although the oak seedling density doubles from unburned plots to virtually any fire occurrence, there are no statistical differences within these values $(\mathrm{p}=0.7150)$. Oaks make up 9-23\% of all seedlings. In contrast to the simple abundance of oak seedlings is their aggregate height per acre (Table 6). Although not statistically significant $(\mathrm{p}=0.2434)$, aggregate oak height is highest in areas that have experienced four wildfires (3549 ft/ac) and lowest in areas that have no recorded fire history (1214 ft/ac).

In applying the oak regeneration model developed by Steiner et al. (2008), expected oak stocking percent peaked in areas of three fires (73\%) (Table 6). This high expected stocking value is largely due to the component of sprout origin (56\%). In stands that have experienced zero to four wildfires, the majority of oak stocking is contributed by stump sprout origins, while expected stocking percentages of seedling origin surpass them in magnitude in areas of five or six fires. The adjusted current oak stocking percentage ranged from 45-69\%. These values are generally more than the predicted oak stocking percentages, especially in the zero to one and five to six burned areas.

Total stocking values were affected by fire occurrence (Table 7). While areas of zero and one burn were slightly overstocked (104 and 106\%), stocking of two to four burns ranged from $82-88 \%$ and highly burned areas were understocked (61\% for five burns, $40 \%$ for six burns). Average gross board foot volume displayed a decreasing trend with increasing fire frequency (11,105-5,659 Bdft/ac) (Table 7). A similar pattern was observed for net volume, decreasing from 11,924 to 4,906 $\mathrm{Bdft} / \mathrm{ac}(\mathrm{p}=0.0003)$. As can be expected, areas that have been subject to 
Table 5 Mean seedling density per acre of living stems $<5 \mathrm{ft}$ in Cabwaylingo State Forest.

\begin{tabular}{|c|c|c|c|c|c|c|c|c|}
\hline & \multicolumn{7}{|c|}{ Wildfire Occurrence } & \multirow{2}{*}{ p-value } \\
\hline & 0 & 1 & 2 & 3 & 4 & 5 & 6 & \\
\hline Total & 17656.3 & 20752.7 & 15840.6 & 17627.0 & 16111.1 & 16428.6 & 17400.0 & 0.8411 \\
\hline Oaks & 1656.3 & 3053.8 & 3304.3 & 2920.6 & 3305.6 & 3761.9 & 2066.7 & 0.7150 \\
\hline White Oaks & 8.8 & 14.5 & 15.5 & 16.6 & 17.1 & 18.6 & 10.6 & \\
\hline Quercus alba & 406.3 & 1419.4 & 608.7 & 500.0 & 27.8 & 619.0 & 1333.3 & \\
\hline Quercus prinus & 687.5 & 1290.3 & 2246.4 & 1531.7 & 2388.9 & 2714.3 & 266.7 & \\
\hline Red Oaks & 8.8 & 14.5 & 15.5 & 16.6 & 17.1 & 18.6 & 10.6 & \\
\hline Quercus coccinea & 31.3 & 0.0 & 43.5 & 0.0 & 0.0 & 0.0 & 0.0 & \\
\hline Quercus falcata & 20.8 & 0.0 & 0.0 & 71.4 & 41.7 & 0.0 & 0.0 & \\
\hline Quercus rubra & 260.4 & 64.5 & 217.4 & 190.5 & 513.9 & 95.2 & 66.7 & \\
\hline Quercus velutina & 250.0 & 279.6 & 188.4 & 627.0 & 333.3 & 333.3 & 400.0 & \\
\hline Non-Oaks & 16000.0 & 17698.9 & 12536.2 & 14706.3 & 12805.6 & 12666.7 & 15333.3 & 0.6040 \\
\hline Acer rubrum & 4916.7 & 6150.5 & 2913.0 & 2769.8 & 1250.0 & 3333.3 & 3266.7 & \\
\hline Acer saccharum & 593.8 & 1709.7 & 246.4 & 79.4 & 0.0 & 0.0 & 0.0 & \\
\hline Amelanchier spp. & 614.6 & 75.3 & 115.9 & 71.4 & 27.8 & 0.0 & 0.0 & \\
\hline Asimina triloba & 177.1 & 172.0 & 173.9 & 87.3 & 27.8 & 0.0 & 0.0 & \\
\hline Betula lenta & 0.0 & 301.1 & 87.0 & 31.7 & 0.0 & 428.6 & 0.0 & \\
\hline Carpinus caroliniana & 0.0 & 0.0 & 14.5 & 0.0 & 0.0 & 0.0 & 0.0 & \\
\hline Carya spp. & 354.2 & 537.6 & 478.3 & 381.0 & 555.6 & 809.5 & 666.7 & \\
\hline Castanea dentata & 0.0 & 32.3 & 14.5 & 31.7 & 0.0 & 0.0 & 0.0 & \\
\hline Cercis canadensis & 1010.4 & 526.9 & 217.4 & 269.8 & 250.0 & 1142.9 & 66.7 & \\
\hline Cornus florida & 385.4 & 247.3 & 188.4 & 150.8 & 13.9 & 571.4 & 66.7 & \\
\hline Fagus grandifolia & 302.1 & 204.3 & 58.0 & 15.9 & 69.4 & 142.9 & 0.0 & \\
\hline Fraxinus spp. & 666.7 & 537.6 & 87.0 & 23.8 & 0.0 & 0.0 & 66.7 & \\
\hline Kalmia latifolia & 447.9 & 720.4 & 347.8 & 1031.7 & 666.7 & 0.0 & 0.0 & \\
\hline Liriodendron tulipifera & 0.0 & 161.3 & 29.0 & 71.4 & 55.6 & 0.0 & 66.7 & \\
\hline Magnolia acuminata & 10.4 & 354.8 & 115.9 & 0.0 & 0.0 & 0.0 & 0.0 & \\
\hline Magnolia tripetala & 31.3 & 10.8 & 0.0 & 0.0 & 0.0 & 0.0 & 0.0 & \\
\hline Nyssa sylvatica & 1010.4 & 1591.4 & 637.7 & 1095.2 & 1416.7 & 809.5 & 2000.0 & \\
\hline Ostrya virginiana & 10.4 & 32.3 & 144.9 & 15.9 & 0.0 & 0.0 & 0.0 & \\
\hline Oxydendrum arboreum & 135.4 & 64.5 & 318.8 & 190.5 & 263.9 & 0.0 & 0.0 & \\
\hline Pinus echinata & 0.0 & 0.0 & 0.0 & 0.0 & 13.9 & 0.0 & 0.0 & \\
\hline Pinus rigida & 0.0 & 0.0 & 0.0 & 0.0 & 13.9 & 0.0 & 0.0 & \\
\hline Pinus strobus & 0.0 & 0.0 & 0.0 & 0.0 & 0.0 & 0.0 & 0.0 & \\
\hline Pinus virginiana & 0.0 & 0.0 & 0.0 & 0.0 & 194.4 & 0.0 & 0.0 & \\
\hline Rhododendron spp. & 1166.7 & 172.0 & 0.0 & 23.8 & 152.8 & 0.0 & 0.0 & \\
\hline Rhus spp. & 0.0 & 0.0 & 173.9 & 71.4 & 194.4 & 47.6 & 200.0 & \\
\hline Robinia pseudoacacia & 0.0 & 96.8 & 101.4 & 7.9 & 55.6 & 428.6 & 400.0 & \\
\hline Sassafras albidum & 3177.1 & 1086.0 & 5014.5 & 7142.9 & 7083.3 & 4476.2 & 8533.3 & \\
\hline Tilia americana & 0.0 & 86.0 & 0.0 & 150.8 & 69.4 & 0.0 & 0.0 & \\
\hline Tsuga canadensis & 10.4 & 0.0 & 0.0 & 0.0 & 0.0 & 0.0 & 0.0 & \\
\hline Ulmus spp. & 197.9 & 1290.3 & 14.5 & 119.0 & 319.4 & 0.0 & 0.0 & \\
\hline Vaccinium spp. & 0.0 & 0.0 & 0.0 & 7.9 & 0.0 & 0.0 & 0.0 & \\
\hline Viburnum acerifolium & 750.0 & 1440.9 & 768.1 & 761.9 & 0.0 & 190.5 & 0.0 & \\
\hline Unknown & 31.3 & 96.8 & 275.4 & 103.2 & 111.1 & 285.7 & 0.0 & \\
\hline
\end{tabular}

${ }^{a}$ Means with the same letters per row show no statistically significant difference $(\alpha=0.05)$. 
Table 6 Summary of oak regeneration characteristics in Cabwaylingo State Forest.

Wildfire Occurrence

\begin{tabular}{|c|c|c|c|c|c|c|c|c|}
\hline & \multicolumn{7}{|c|}{ Wildfire Occurrence } & \multirow{2}{*}{ p-value } \\
\hline & 0 & 1 & 2 & 3 & 4 & 5 & 6 & \\
\hline $\begin{array}{r}\text { Aggregate Oak Seedling } \\
\text { Height (ft/ac) }\end{array}$ & 1213.5 & 2133.3 & 2284.7 & 2523.8 & 3548.6 & 2738.1 & 2300.0 & 0.2434 \\
\hline Current Oak Stocking (\%) * & 51.9 & 45.3 & 59.1 & 69.0 & 54.9 & 63.9 & 67.5 & \\
\hline Expected Oak Stocking (\%) & 30.5 & 31.7 & 50.4 & 73.0 & 48.1 & 29.4 & 17.4 & \\
\hline Sprouting Origin Stocking (\%) & 21.1 & 16.2 & 37.1 & 55.7 & 27.8 & 11.6 & 5.8 & \\
\hline Seedling Origin Stocking (\%) & 9.4 & 15.5 & 13.4 & 17.2 & 20.4 & 17.8 & 11.6 & \\
\hline
\end{tabular}

${ }^{\dagger}$ Square root transformation was used for ANOVA.

* Adjusted for full (100\%) stand stocking based on Gingrich (1967).

${ }^{a}$ Means with the same letters per row show no statistically significant difference $(\alpha=0.05)$. 
Table 7 Wildfire impact on timber volume and value in Cabwaylingo State Forest.

Wildfire Occurrence

\begin{tabular}{|c|c|c|c|c|c|c|c|c|}
\hline & \multicolumn{7}{|c|}{ 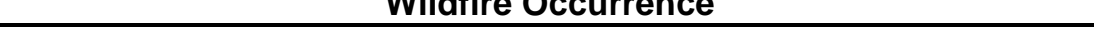 } & \multirow{2}{*}{ p-value } \\
\hline & 0 & 1 & 2 & 3 & 4 & 5 & 6 & \\
\hline Total Stocking (\%) & 104 & 106 & 88 & 87 & 82 & 61 & 40 & \\
\hline Gross Volume (Int'l 1/4" Bdft/ac) & 11,105 & 10,519 & 9,160 & 7,992 & 6,746 & 6,102 & 5,659 & \\
\hline 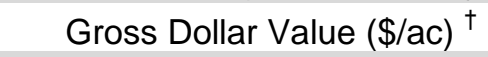 & $1,284.23$ & $1,168.57$ & $1,078.58$ & 876.25 & 751.86 & 761.19 & 664.76 & \\
\hline Lost Volume (Int'l 1/4" Bdft/ac) & 181 & 238 & 449 & 326 & 363 & 420 & 752 & 0.3805 \\
\hline 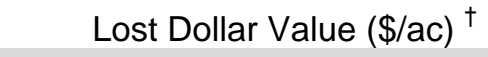 & 16.09 & 23.38 & 56.18 & 33.11 & 49.33 & 56.34 & 75.39 & \\
\hline Net Volume (Int'I 1/4" Bdft/ac) & $10,924^{a}$ & $10,281^{a}$ & $8,711^{\mathrm{ab}}$ & $7,666^{b}$ & $6,383^{b}$ & $5,682^{b}$ & $4,906^{b}$ & 0.0003 \\
\hline Net Dollar Value $(\$ / a c)^{\dagger}$ & $1,268.14$ & $1,145.19$ & $1,022.40$ & 843.13 & 702.54 & 704.85 & 589.37 & \\
\hline Dollar Value Loss (\%) & 0 & 9.7 & 19.4 & 33.5 & 44.6 & 44.4 & 53.5 & \\
\hline
\end{tabular}

\footnotetext{
${ }^{\dagger}$ Values are based on species timber prices of June 2009 listed for Region 5 by the Appalachian Hardwood Center.

${ }^{a}$ Means with the same letters per row show no statistically significant difference $(\alpha=0.05)$.
} 
repeated wildfires show greater losses in gross and net volumes of standing trees and higher damage due to cull board foot volume. Although volume loss due to damaged bole sections showed no statistical significance $(\mathrm{p}=0.3805)$, mean values generally increased with recurring fires (181-752 Bdft/ac). The greatest net dollar value per acre was calculated for unburned stands $(\$ 1,268 / \mathrm{ac})$ while the lowest average resulted from plots of six fires $(\$ 589 / \mathrm{ac})$. 


\section{DISCUSSION}

This study clearly shows that wildfires - especially repeated wildfires - have distinctly shaped forest stands in CSF. Wildfire frequency had an effect on a variety of stand parameters including density and composition. The impact on the different strata within these stands varies as does the number of fires required to show distinct change in each.

Total tree density, basal area, and stocking decrease with increasing fire disturbances. This is especially true for fire sensitive species such as red maple and blackgum. Yet oak overstory density is greatest in stands that have experienced three or four fires. Important adaptations aiding mature oaks to withstand fire are the thick bark that may char on the outside but protects the underlying cambium from damage and a resistance to rot (Van Lear and Watt 1992). Overstory oak with large diameters do not appear to be severely impacted by wildfires. Changes in the densities of smaller diameter trees (2- 8 inches DBH) are notable across the different fire regimes. In particular, an increase of small diameter oaks and decrease in small diameter non-oaks can be observed in medium burned plots (two to four fires). Here, fire has clearly created a competitive advantage for the oaks and created a size class distribution that is typical of self-sustaining populations (reverse-J).

Total density of sapling-sized trees shows a generally increasing trend with higher fire occurrence; these increases are primarily due to higher numbers of blackgum, sassafras, and black locust (Robinia pseudoacacia L.). These fast-growing species are often associated with early succession stands (Boring et al. 1981). Oak sapling density increases dramatically from zero to two fires. Consistent with the higher density of small overstory oaks, there are increased numbers of oak saplings in the medium burn frequencies; the highest oak sapling density is found in four burn plots. Signell et al. (2005) found oak sapling densities in burned forests in 
Pennsylvania averaged 354 stems/ac compared to only 12 stems/ac in unburned stands with highest abundances where overstory density was less than 161 TPA. This finding coincides with our results in four-burned areas.

Seedlings are the result of a relatively short growing period and may be impacted in density by disturbances that have occurred in the sample year and possibly one or two years prior. Spring fires have been suggested to be more lethal on vegetation than fires during other seasons (Barnes and Van Lear 1998). During the spring of our field sampling, there were no recorded fires in CSF affecting our plots. Different wildfire frequencies did not significantly impact seedling density of either oaks or non-oaks. CSF seems to harbor about 1,700 seedlings per acre across all fire areas, with oak seedlings comprising $10-20 \%$ of the total. Seedlings of all species seem to germinate or sprout, at least after fire absence in the spring.

Mean aggregate oak seedling height per acre doubles from control plots $(1,200 \mathrm{ft} / \mathrm{ac})$ to all other wildfire areas and even triples in the four-burned treatments. These results support the argument that repeated top-killing of seedlings, resulting in large root: shoot ratios, produces seedling sprouts that grow more aggressively, thus gaining a height advantage over the competition (Carvell and Tryon 1961, Johnson 1992). In contrast, diminished aggregate height in areas burned five and six times might be the result of fire-free intervals that are not long enough to produce this kind of height in seedling sprouts.

The method we adopted from Steiner et al. (2008) to evaluate oak stocking potential reflected the importance of high aggregate oak height in four-burn areas and small diameter overstory trees in the three-burned plots. Current and predicted combined oak stocking values are closest in areas burned two to four times. Large discrepancies between the predicted future oak stocking and current oak stocking are found in the low (zero and one) and high (five and six) 
wildfire areas. If the model by Steiner et al. (2008) predicts future oak stocking correctly, it can be argued that these low and high wildfire areas are still in flux and can be expected to change in seedling, sapling, and overstory DBH distribution and density with continuation of the current fire regime. Decreases in oak stocking should be expected in those low and high fire regions if existing mean disturbance patterns prevail. The same line of thought would imply that some sort of state has been reached in the mid-burn plots, where the amount of oak regeneration present is sufficient in maintaining a consistent overstory component. If the current stocking numbers are constant, however, then the model gravely underestimates the ability of oaks to successfully regenerate in low and high fire areas.

Oak seedling aggregate height, sapling density, and small diameter overstory trees seem to respond favorably to the three and four burn occurrences. The elevated aggregate height in the four-burned plots translates into a significantly higher density of oak saplings there compared to any of the other treatments. Seedlings as well as saplings make up $21 \%$ of the respective totals whereas on other plots, the percentage of oak saplings is less than half that of seedlings compared to non-oaks. Seedlings seem to get recruited into the sapling stage more successfully here. However, four or more fires create a problem for the consequent recruitment of oak saplings into the overstory. Thus, there seems to exist a window in which fire frequency is "just enough but not too much". Fire can greatly increase the competitiveness of oak advance reproduction on certain sites if occurring in the right stand at the right time. In order to create management guidelines about using fire to establish successful oak regeneration, it may not be enough to simply "average out" a certain number of burns over a defined period of time. For successful recruitment from one regeneration level into the next, it is likely that the fire intervals of repeated fires must change as the stand ages. Arguably, fires might be most effective in 
creating a strong seedling sprout stock and keeping competing species low when staggered relatively close together at the beginning of a rotation, then increasing the fire-free periods to allow for sapling development and recruitment into the overstory until a fairly fire-resistant DBH is attained. Other sources have stated that fires are beneficial to advance oak reproduction only when both overstory and understory are reduced in density (Signell et al. 2005). Prescribed burning has been suggested to be used in areas with naturally high seedling establishment and in application with significant overstory reduction cutting (Brose et al. 2006).

We draw our conclusions cautiously as some of our comparisons failed to show statistical significance and we designated treatment groups according to their overall wildfire history of the past 36 years, not taking into account the length of fire-free periods therein or time period since the last fire before sampling. It is important to note that these are wildfires; we have no measure of intensity and the study was not designed to analyze potential fire impact based on season of burning or fire intervals. Furthermore, we observed a distinct "patchiness" of oak seedlings. Virtually all treatments had seedling plots void of oak seedlings, while the actual difference between burn plots was demonstrated on patches that had oak seedlings present. A similar patchiness with high variability was also reported by Signell et al. (2005). Such a seedling distribution in forests could result from animal caches of acorns and the important influence of microclimates in acorn sprouting. Environmental factors other than fires also heavily influence the success of any plant species. Because of the boundaries of our study area, our sample sizes in the five and six burn groups are relatively small, most of them being located at higher elevations and south-facing slopes.

Rarely are state forests managed for a single genus. While fire - even wildfire - appears to be beneficial to oak regeneration to some degree, its impact on the entire stand matrix must be 
taken into account before making a management decision. One of the biggest concerns regarding wildfires is the damage it does to timber volumes and quality and the negative monetary impact it might have. Asides from sawmill prices, the monetary timber value of a stand is due to three major factors: standing tree volume, damage done to this volume, and species composition.

Stand stocking, as determined by basal area and density, was heavily impacted by fire; the more fires a stand experienced, the lower the stocking. Additionally, the volume of merchantable timber declined and loss due to cull increased as wildfires became more frequent. The resulting net volume values show a significantly declining trend; stands that experienced fewer fires had significantly higher net board foot volumes. The calculated net dollar values per acre reflect influences of stocking, fire damage to volume, and any shifts in species composition - reflected in species specific timber prices - across the wildfire regimes.

The wildfires in CSF further fueled the debate of whether fire holds some benefit to the forest or not. Oaks are one of the most important wildlife species in Appalachian forest and many desire to increase oak components in stands. Two to four wildfires over a 36-year period seem to have put stands on a track into that direction. For controlled burning to further oak regeneration, it has been suggested that fires are best combined with an overstory thinning (Brose et al. 2006). Wildfires that might burn hotter and more intensely than prescribed fires reduce overstory density on their own; understory density is influenced by both kind of fires. Wildfires act like a manager in reducing the overstory without, however, the added bonus of timber sales, consuming the volume instead. Decreased overstory density enhances the regeneration of shade intolerant and intermediate species. Nonetheless, the more wildfires a stand experiences, the less stumpage value it holds in timber. Managers must now weigh the benefits and drawbacks of wildfires as they try to achieve the most productive and valuable 
stands possible while being limited by budgets and many uncontrollable as well as some unknown factors that influence the practice of forestry. 


\section{LITERATURE CITED}

Abrams, M.D. 1990. Adaptations and responses to drought in Quercus species of North America. Tree Physiology 7: 227-238.

Abrams, M.D. 1992. Fire and the development of oak forests. BioScience 42(5): 346-353.

Arthur, M.A.; Paratley, R.D.; Blankenship, B.A. 1998. Single and repeated fires affect survival and regeneration of woody and herbaceous species in an oak-pine forest. Journal of the Torrey Botanical Society 125(3): 225-236.

Appalachian Hardwood Center. 2009. http://ahc.caf.wvu.edu. Accessed: November 20, 2009.

Barnes, T.A.; VanLear, D.H. 1998. Prescribed fire effects on advanced regeneration in mixed hardwood stands. Southern Journal of Applied Forestry 22(3): 138-142.

Beck, D.E. 1992. Acorns and oak regeneration. In: Loftis, D.L.; McGee, C.E. Oak regeneration: serious problems, practical recommendations (symposium proceedings); September 8-10, 1992; Knoxville, TN. USDA Forest Service, Southeastern Forest Experiment Station, General Technical Report SE-84: 96-104.

Belli, K.L; Hart, C.P.; Hodges, J.D.; Stanturf, J.A. 1999. Assessment of the regeneration potential of red oaks and ash on minor bottoms of Mississippi. Southern Journal of Applied Forestry 23(3): 133-138.

Boring, L.R.; Monk, C.D.; Swank, W.T. 1981. Early regeneration of a clear-cut southern Appalachian forest. Ecology 62: 1244-1253.

Brose, P.; Schuler, T.; Van Lear, D.; Berst, J. 2001. Bringing fire back: the changing regimes of the Appalachian mixed-oak forest. Journal of Forestry 99: 30-35.

Brose, P.; Schuler, T.; Ward, J. 2006. Responses of oak and other hardwood regeneration to prescribed fire: what we know as of 2005. In: Dickinson, M.B. Fire in eastern oak forests: delivering science to land managers (conference proceedings); November 15-17, 2005; Columbus, OH. USDA Forest Service, Northern Research Station, General Technical Report NRS-P-1: 123-135.

Carvell, K.L.; Tryon, E.H. 1961. The effect of environmental factors on the abundance of oak regeneration beneath mature oak stands. Forest Science 7(2): 98-105.

Copenheaver, C.A.; Matthews, J.M.; Showalter, J.M.; Auch, W.E. 2006. Forest stand development patterns in the southern Appalachians. Northeastern Naturalist 13(4): 477 494.

Delcourt, H.R.; Delcourt, P.A. 1997. Pre-Columbian Native American use of fire on southern Appalachian landscapes. Conservation Biology 11(4): 1010-1014. 
Environmental Systems Research Institute, (ESRI). 2003. ArcGIS Desktop ArcMap, Spatial Analyst, Version 9.2. Redlands California, USA.

Feret, P.P.; Kreh, R.E.; Merkle, S.A.; Oderwald, R.G. 1982. Flower abundance, premature acorn abscission, and acorn production in Quercus alba L. Botanical Gazette 143(2): 216-218.

Gilbert, N.L.; Johnson, S.L.; Gleeson, S.K.; Blankenship, B.A.; Arthur, M.A. 2003. Effects of prescribed fire on physiology and growth of Acer rubrum and Quercus spp. seedlings in an oak-pine forest on the Cumberland Plateau, KY. Journal of the Torrey Botanical Society 130(4): 253-264.

Gingrich, S.F. 1967. Measuring and evaluating stocking and stand density in upland hardwood forests in the central states. Forest Science 13: 38-53.

Hodges, J.D.; Gardiner, E.S. 1992. Ecology and physiology of oak regeneration. In: Loftis, D.L.; McGee, C.E. Oak regeneration: serious problems, practical recommendations (symposium proceedings); September 8-10, 1992; Knoxville, TN. USDA Forest Service, Southeastern Forest Experiment Station, General Technical Report SE-84: 54-65.

Johnson, P.S. 1977. Predicting oak stump sprouting and sprout development in the Missouri Ozarks. USDA Forest Service, North Central Forest Experiment Station, Research Paper NC-149. $11 \mathrm{p}$.

Johnson, P.S. 1992. Sources of oak reproduction. In: Loftis, D.L.; McGee, C.E. Oak regeneration: serious problems, practical recommendations (symposium proceedings); September 8-10, 1992; Knoxville, TN. USDA Forest Service, Southeastern Forest Experiment Station, General Technical Report SE-84: 112-131.

Johnson, P.S.; Shifley, S.R. 2002. The ecology and silviculture of oaks. CABI Publishing, Wallingford and New York. 503 p.

Johnson, R.L. 1980. New ideas about regeneration of hardwoods. In: Hardwood committee's symposium on oak regeneration (symposium proceedings). January 29, 1980; Atlanta, GA: 17-19.

Kolb, T.E.; Steiner, K.C. 1990. Growth and biomass partitioning of northern red oak and yellow poplar seedlings: effects of shading and grass root competitions. Forest Science 36(1): 34-44.

Lorimer, C.G. 1992. Causes of the oak regeneration problem. In: Loftis, D.L.; McGee, C.E. Oak regeneration: serious problems, practical recommendations (symposium proceedings); September 8-10, 1992; Knoxville, TN. USDA Forest Service, Southeastern Forest Experiment Station, General Technical Report SE-84: 14-39. 
Lorimer, C.G. 2001. Historical and ecological roles of disturbance in eastern North American forests: 9,000 years of change. Wildlife Society Bulletin 29(2): 425-439.

Lorimer, C.G.; Chapman, J.W.; Lambert, W.D. 1994. Tall understorey vegetation as a factor in the poor development of oak seedlings beneath mature stands. Journal of Ecology 82: 227-27.

Lowell, E.C.; Willits, S.A.; Krahmer, R.L. 1992. Deterioration of fire-killed and fire-damaged timber in the western United States. USDA Forest Service, Pacific Northwest Research Station, General Technical Report PNW-GTR-292. 36p.

Nowacki, G.J.; Abrams, M.D. 2008. The demise of fire and "mesophication" of forest in the eastern United States. BioScience 58(2): 123-138.

Sander, I.L. 1972. Size of oak advance reproduction: key to growth following harvest cutting. USDA Forest Service, North Central Forest Experiment Station, Research Paper NC-79. $11 \mathrm{p}$.

Sander, I.L.; Johnson, P.S.; Rogers, R. 1984. Evaluating oak advance reproduction in the Missouri Ozarks. USDA Forest Service, North Central Forest Experiment Station, Research Paper NC-251. 19 p.

SAS Institute Inc., SAS 9.1.3 Help and Documentation, Cary, NC: SAS Institute Inc., 20002004.

Sharp, W.M.; Sprague, V.G. 1967. Flowering and fruiting in the white oaks. Pistillate flowering, acorn development, weather and yields. Ecology 48(2): 243-251.

Signell, S.A.; Abrams, M.D.; Hovis, J.C.; Henry S.W. 2005. Impact of multiple fires on stand structure and tree regeneration in central Appalachian oak forests. Forest Ecology and Management 218: 146-158.

Smith, D.W. 1992. Oak regeneration: the scope of the problem. In: Loftis, D.L.; McGee, C.E. Oak regeneration: serious problems, practical recommendations (symposium proceedings); September 8-10, 1992; Knoxville, TN. USDA Forest Service, Southeastern Forest Experiment Station, General Technical Report SE-84: 40-52.

Steiner, K.C.; Finley, J.C.; Gould, P.J.; Fei, S.; McDill, M. 2008. Oak regeneration guidelines for the central Appalachians. Northern Journal of Applied Forestry 25(1): 5-16.

Van Lear, D.H.; Waldrop, T.A. 1989. History, uses, and effects of fire in the Appalachians. USDA Forest Service, Southeastern Forest Experiment Station, Genera Technical Report SE-54. 20p. 
Van Lear, D.H; Watt, J.M. 1992. The role of fire in oak regeneration. In: Loftis, D.L.; McGee, C.E. Oak regeneration: serious problems, practical recommendations (symposium proceedings); September 8-10, 1992; Knoxville, TN. USDA Forest Service, Southeastern Forest Experiment Station, General Technical Report SE-84: 66-78.

Williamson, M.J. 1966. Premature abscission in white oak acorn production. Forest Science 12: $19-21$.

West Virginia Division of Forestry. 2001. http://www.wvforestry.com. Accessed: October 28, 2009.

West Virginia Division of Forestry, Milton, WV office. Arnold, K.I., regional forester. P.O. Box 189 (Street Address: 878 E. Main Street), Milton, West Virginia 25541.

West Virginia GIS Technical Center. 2008. http://wvgis.wvu.edu. Accessed: March 2008. 